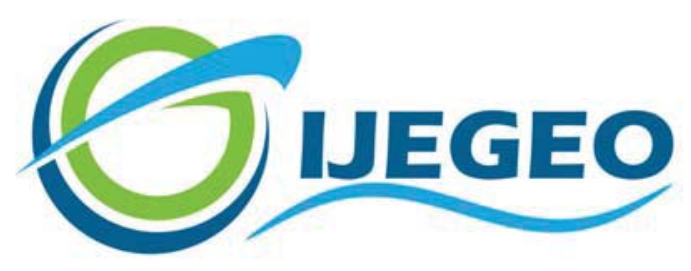

International Journal of Environment and Geoinformatics (IJEGEO) is an international, multidisciplinary, peer reviewed, open access journal.

\title{
Geological Features and Lithostratigraphy of Eocene-Oligocene Magmatic Rocks in the Dededağ Area-Biga Peninsula, NW Turkey
}

\section{Oya ERENOĞLU, Mustafa BOZCU}

\author{
Chief in Editor \\ Prof. Dr. Cem Gazioğlu \\ Co-Editors \\ Prof. Dr. Dursun Zafer Şeker, Prof. Dr. Şinasi Kaya, \\ Prof. Dr. Ayşegül Tanık and Assist. Prof. Dr. Volkan Demir
}

Editorial Committee (December 2021)

Assoc. Prof. Dr. Abdullah Aksu (TR), Assit. Prof. Dr. Uğur Algancı (TR), Prof. Dr. Bedri Alpar (TR), Assoc. Prof. Dr. Aslı Aslan (US), Prof. Dr. Levent Bat (TR), Prof. Dr. Paul Bates (UK), İrşad Bayırhan (TR), Prof. Dr. Bülent Bayram (TR), Prof. Dr. Luis M. Botana (ES), Prof. Dr. Nuray Çağlar (TR), Prof. Dr. Sukanta Dash (IN), Dr. Soofia T. Elias (UK), Prof. Dr. A. Evren Erginal (TR), Assoc. Prof. Dr. Cüneyt Erenoğlu (TR), Dr. Dieter Fritsch (DE), Prof. Dr. Çiğgem Göksel (TR), Prof.Dr. Lena Halounova (CZ), Prof. Dr. Manik Kalubarme (IN), Dr. Hakan Kaya (TR), Assist. Prof. Dr. Serkan Kükrer (TR), Assoc. Prof. Dr. Maged Marghany (MY), Prof. Dr. Michael Meadows (ZA), Prof. Dr. Nebiye Musaoğlu (TR), Prof. Dr. Masafumi Nakagawa (JP), Prof. Dr. Hasan Özdemir (TR), Prof. Dr. Chryssy Potsiou (GR), Prof. Dr. Erol Sarı (TR), Prof. Dr. Maria Paradiso (IT), Prof. Dr. Petros Patias (GR), Prof. Dr. Elif Sertel (TR), Prof. Dr. Nüket Sivri (TR), Prof. Dr. Füsun Balık Şanlı (TR), Prof. Dr. Uğur Şanlı (TR), Duygu Ülker (TR), Prof. Dr. Seyfettin Taş (TR), Assoc. Prof. Dr. Ömer Suat Taşkın (TR), Assist. Prof. Dr. Tuba Ünsal (TR), Dr. Manousos Valyrakis (UK), Dr. İnese Varna (LV), Dr. Petra Visser (NL), Prof. Dr. Selma Ünlü (TR), Assoc. Prof. Dr. Oral Yağcı (TR), Prof. Dr. Murat Yakar (TR), Assoc. Prof. Dr. İ. Noyan Yılmaz (AU); Assit. Prof. Dr. Sibel Zeki (TR) 


\title{
Geological Features and Lithostratigraphy of Eocene-Oligocene Magmatic Rocks in the Dededağ Area-Biga Peninsula, NW Turkey
}

\author{
Oya Erenoğlü 1,* iD, Mustafa Bozcu ${ }^{2}$ iD \\ ${ }^{1}$ Canakkale Onsekiz Mart University, Faculty of Education, Department of Geographical Education, Canakkale, TR \\ ${ }^{2}$ Canakkale Onsekiz Mart University, Faculty of Engineering, Canakkale, Department of Geological Engineering, Canakkale, TR \\ * Corresponding author: Oya Erenoğlu \\ Received 26.02.2021 \\ E-mail: o_turkdonmez@comu.edu.tr \\ Accepted 21.08.202 \\ How to cite: Erenoğlu and Bozcu (2021). Geological Features and Lithostratigraphy of Eocene-Oligocene Magmatic Rocks in the Dededağ \\ Area-Biga Peninsula, NW TR. International Journal of Environment and Geoinformatics (IJEGEO), 8(4): 435-3XX. doi. \\ 10.30897/ijegeo.887149
}

\begin{abstract}
In NW Anatolia, Eocene-Oligocene post-collisional magmatism continued over long intervals. In this study, the aim is to reveal the lithostratigraphic position and geochemical characteristics of volcanic rocks outcropping southeast of Lapseki (Çanakkale) in NW Anatolia. The magmatic rocks that comprise the topic of this study can be classified lithostratigraphically into 6 different units in the region. In the Eocene period, there are calc-alkaline Laledağ granodiorite and Beyçayır volcanic rocks with andesite and dacite composition and intermediate character, and also Kızıldam volcanic rocks with alkaline and basic character (basaltic trachyandesite, trachybasalt). Furthermore, in the Oligocene period, calc-alkaline volcanism starting with Dededağ volcanics, which have dacite and rhyolite composition and acidic-intermediate character, continued with the Kircalar volcanics consisting of basalt and basaltic andesite, and the Harmancık volcanics ranging from basalt to rhyolite. The Çamyayla Pluton intruded into Oligocene volcanic rocks in the region. In this study, the geochemical data proved that magmatic units have alkaline and calc-alkaline character in the EoceneOligocene period. Alkaline lavas in the region are classified as high $\mathrm{K}$ and shoshonitic and calc-alkaline lavas are medium-high-K.
\end{abstract}

Keywords: Lithostratigraphy, Eocene-Oligocene Magmatism, Geochemistry, Biga Peninsula, NW Anatolia

\section{Introduction}

Magmatism that started in the Eocene period following the collision of the Sakarya continent and AnatolideTauride continent during the Upper Cretaceous-Early Eocene in the Biga Peninsula has been studied by many researchers for long years. As a result of thickening of the continental crust at the end of the Eocene, anatectic melts and granitic intrusions were emplaced as shallow intrusions (Y1lmaz, 1989). Geological, geochronological and petrological studies about plutons that reached shallow depths, such as Karabiga, Kapıdağ, Dikmen, Kuşçayır, Kestanbol, Evciler and Yenice plutons in the region and their stocks, indicate intermediate-felsic granitoid family, which continued their development from the late Eocene to the early Miocene (Bingöl et al., 1982; Birkle and Satır, 1995; Karacık, 1995; Genç, 1998; Delaloye and Bingöl, 2000; Okay and Satır, 2000; Y1lmaz et al., 2001; Karacik et al., 2008; Aysal, 2015; İncekara et al., 2017; Shaheen Zafar et al., 2018; Aydın et al., 2019). Volcanism accompanied plutonism simultaneously and reached the most widespread outcrops.

In most studies about volcanic rocks in the Biga Peninsula, calc-alkaline volcanism, which started in the Eocene after collision, intensified from the Oligocene to the Miocene, and changed its character under a new tectonic regime (stress) after the Upper Miocene. It was stated that it manifests itself in stages (Borsi et al., 1972;
Krushensky, 1976; Dayal, 1984; Siyako et al., 1989; Ercan et al., 1995; Dayal and Özgenç, 2000; Aldanmaz et al., 2000; Kaymakçı et al., 2007; Altunkaynak and Young, 2008; Aysal et al., 2011; Erdem and Aslan, 2015; Aslan et al., 2017; Saatci and Aslan, 2018). As a matter of fact, the studies carried out on outcrops of Eocene volcanism in the Armutlu peninsula to the east of the study area suggest that a post-collision magmatic regime was effective in the Middle Eocene (Gülmez et al., 2012; Altunkaynak and Dilek, 2013). All studies carried out in the Biga Peninsula have an important place in terms of the composition, character, origin and geodynamics of plutonic and volcanic rocks.

In this study, we aimed to discuss the magmatic rocks of Dededag and its surroundings in the north of Biga Peninsula in NW Anatolia, where the products of Eocene and Oligocene volcanism, which are stated to be Eocene stratigraphically by Siyako et al. (1989) and Ercan et al. (1995), occur together. The purpose of this work is to improve the stratigraphic framework of these rocks. The studies dealing with magmatic rocks observed in the study area are limited. In these studies, a clear volcanostratigraphy was not revealed, and the approach of volcanism to temporal evolution is inadequate in terms of regional geochemistry, petrology, and limited geochronology. Therefore, in this study, firstly, the aim was to map the different volcanic units in Dededağ and its surroundings in detail and lithostratigraphic units that will form the basis of future studies about volcanism 
were proposed. Geochemical characterization aimed to evaluate the chemical differences between lavas throughout the stratigraphic sequence of the studied magmatic rocks. Different volcanic facies mapped in the study area were named considering previous studies in the literature. Since most of the nomenclatures represent the peninsula in general, they are very general in terms of clearly revealing different volcanic facies and their formation conditions. In this study, some new nomenclature was required in areas where the separation of volcanic facies was studied in more detail.

\section{Materials and Methods}

Detailed mapping was carried out during field studies in order to determine the characteristics, changes and relations of magmatic rock types distributed in the study area. The compositions of different lithological units and their primary properties such as textures, structures, grain size, vesicles and superficial lava flows were used for lithostratigraphic differentiation. The mineral assemblages and rock groups in each volcanic unit were determined by comparing the lithologically differentiated magmatic rocks with each other petrographically and geochemically. Fresh samples were selected for analytical work by choosing the most representative samples and representing the complete petrographic variations present within stratigraphic levels of the volcanic units. Thin sections of our samples (160 in total) were examined under a polarizing microscope to determine the petrographic properties of all rocks.

As a result of the petrographic examinations, samples as fresh as possible were selected to represent each unit in the best possible way, and major element analyses of these samples were made. A total of 61 rock samples from the magmatic series in the study area were sent to ALS Chemex Laboratory (Canada). Major elements were studied using the Inductively Coupled PlasmaAtomic Emission Spectrometry (ICP-AES) method. Geochemical classifications of intrusive, lava and pyroclastic products in different magmatic units were made by evaluating the geochemical data, and their geochemical characteristics were determined.

\section{Geological Setting and and Local Stratigraphy}

The study area, the Dededağ region, is located southeast of the town of Lapseki in the north of the Biga Peninsula in NW Turkey. In the Dededağ area, different rock units consisting of metamorphic, magmatic and sedimentary rocks are divided into 10 lithostratigraphic units. These are the Kemer metamorphics, which form the basement of the study area, Laledağ granodiorite outcropping in the north of the region, Sogucak limestone and Ceylan formation intercalated with volcanic rocks, the volcanic assemblage outcropping over a wide area in the region, and the Çamyayla granite that was emplaced by cutting the volcanic assemblages (Figures 1 and Figure 2).

Lithologies that form the volcanic assemblage in the region are composed of flow breccia, lava and pyroclastics. Considering the differences in space and time, this volcanic assemblage is divided into 5 separate lithostratigraphic units: Beyçayır volcanics, Kızıldam volcanics, Dededağ volcanics, Kırcalar volcanics and Harmancik volcanics. When the contact relations of the volcanic units with the metamorphic basement and sedimentary sequence are evaluated together, the volcanism started with the Beyçayır volcanics (Bv), followed by the Kizildam volcanics (Kzv) and then the Dededağ (Dv), Kircalar (Krv) and Harmancık volcanics $(\mathrm{Hv})$. The Çamyayla granite, on the other hand, was emplaced into the rocks of the Harmanckk volcanics.

\section{Eocene Magmatic Rocks}

Following the collision of the Sakarya continent and the Anatolide-Tauride platform, the Middle Eocene volcanoplutonic rock association formed in the northern part of the Biga Peninsula south of the Marmara Sea. Eocene plutonic rocks are located in the bedrock of the Sakarya continent. The volcanism of this period is observed between Lapseki-Biga district centers and also in Gelibolu Peninsula in the west. Volcanic products are mostly observed interspersed with sedimentary rocks forming in the marine environment. The composition of volcanic rocks varies from basalt to dacite.
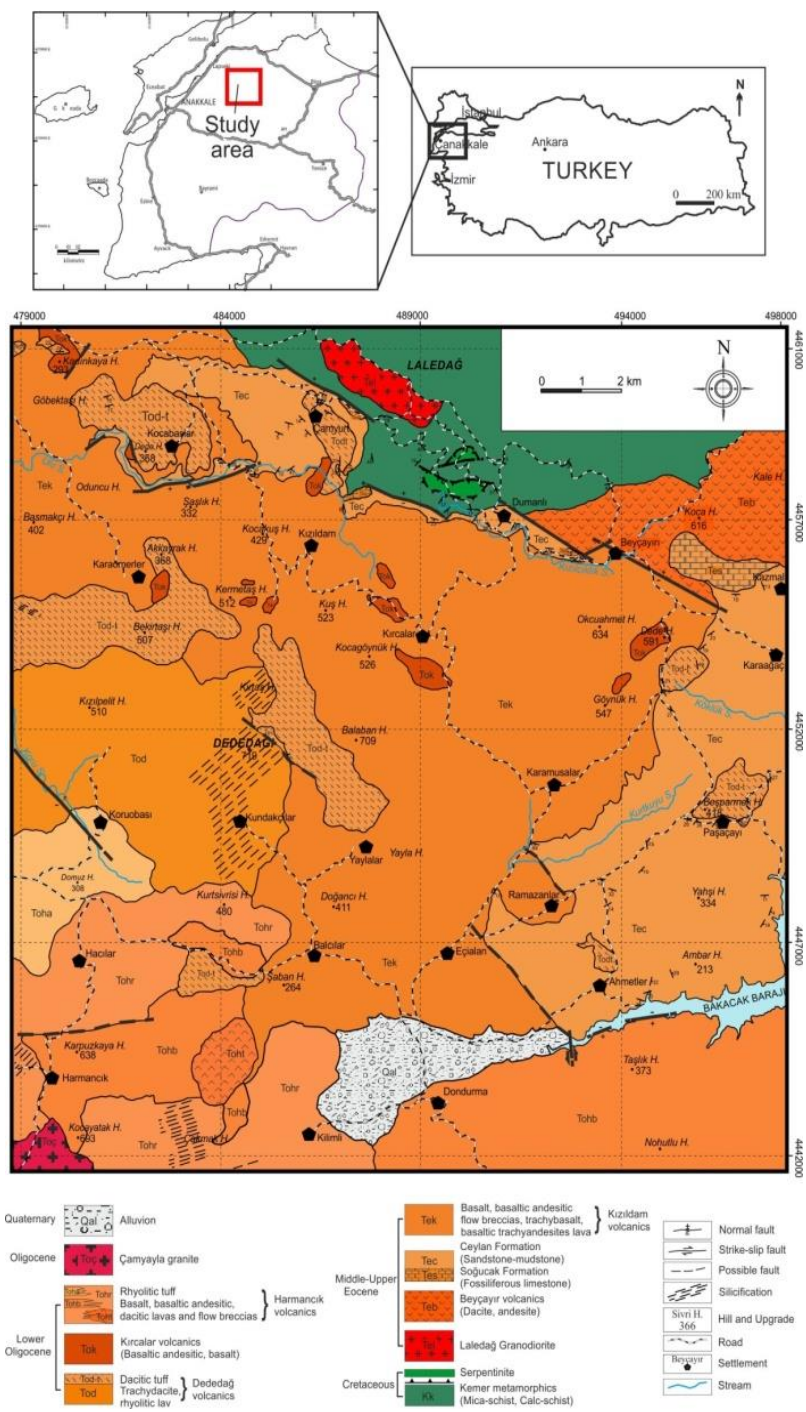

Figure 1. Location and the geological maps of the Dededağ area and its environment. 


\section{Laledag Granodiyorite}

Laledag intrusive located in the north of the study area is a NW-SE trending mass emplaced as a stock. A granodioritic pluton, the Laledag granodiorite is named and comprehensively considered for the first-time in this study. It is observed in an area of approximately $3 \mathrm{~km}^{2}$. The metamorphic rocks in the basement of the region are also intruded by granodioritic pluton (Figure 3a).

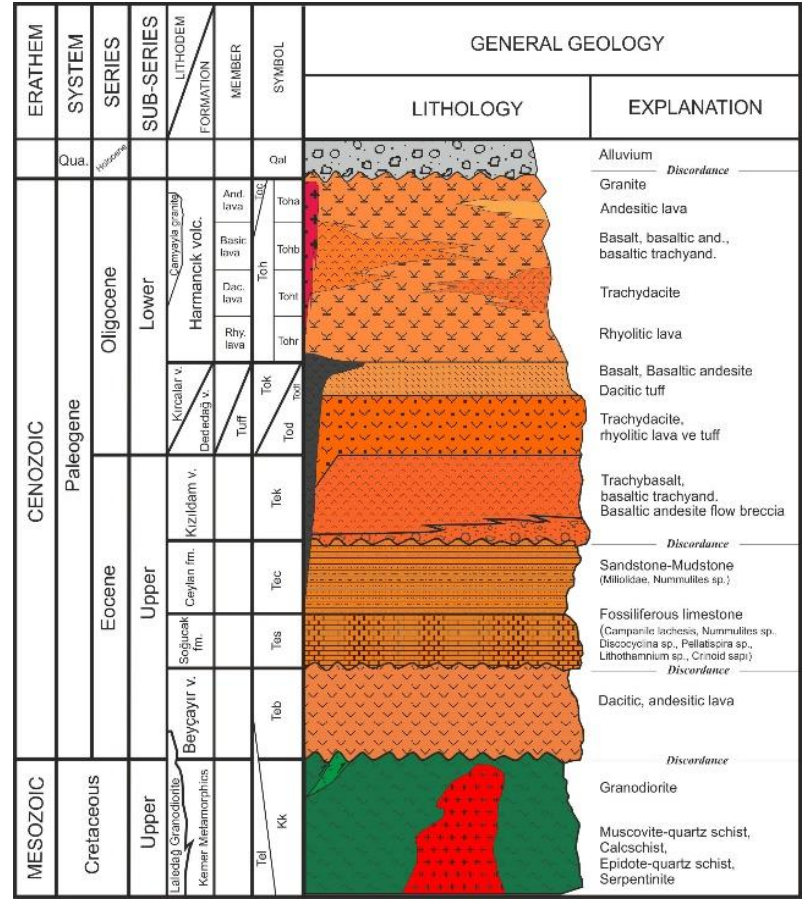

Figure 2. Generalized stratigraphic section of the study area (not to scale).

The Laledağ intrusive has phaneritic texture. Generally, joint systems are developed, with abundant fractures and fractured structures observed in outcrops. This caused global segregation. It is generally observed to be arenitized in its outcrops. Felsic and mafic minerals are quite coarse in areas with fresh surfaces and they are also cut by thin aplitic dykes of 2-7 cm thickness (Figure 3b). Occasionally mafic enclaves were found in the mass (Figure 3c). Although these are not very common, their sizes reach approximately $5-20 \mathrm{~cm}$.

\section{Beyçayır Volcanics}

Beyçayır volcanics are volcanic products, consisting of andesitic and dacitic lavas, which are widely observed in Beyçayır village and its surroundings, and cover part of the Akçaalan (Siyako et al., 1989) and Balıklıçeşme (Ercan et al., 1995) volcanics. It is observed as massive lavas in the study area (Figure 4a). On the clean surfaces of dacites observed in the region, the light green color resulting from chloritization is seen. Plagioclase among felsic minerals, biotite and amphibole minerals among mafic minerals are easily distinguished by the presence of medium-coarse euhedral, subhedral phenocrysts in these lavas which have porphyritic texture (Figure $4 b$ ).
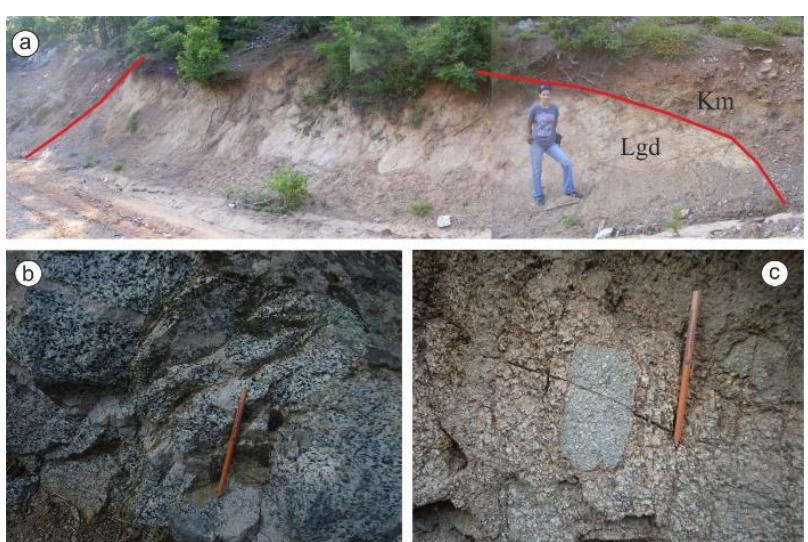

Figure 3. (a) Laledağ granodiorite (Lgd) intrusively cutting the basement rock (Km: Kemer metamorphics) (UTM Zone 35: 487216 E, 4457544 N), (b) Thin aplite dykes cutting Laledag granodiorite (UTM: 486793 E, 4460619 N), (c) Mafic enclaves observed in granodiorite (UTM: 488152 E, 4460152 N).

Beyçayır volcanics have a contact relationship with Kemer metamorphics and Eocene sediments in the study area (Figure 5). It has a tectonic contact with the Kemer metamorphics north of Beyçayır village. In addition, the contact relations with the sedimentary units in the region are discordant, and there appears to be a tectonic contact with the Ceylan formation.
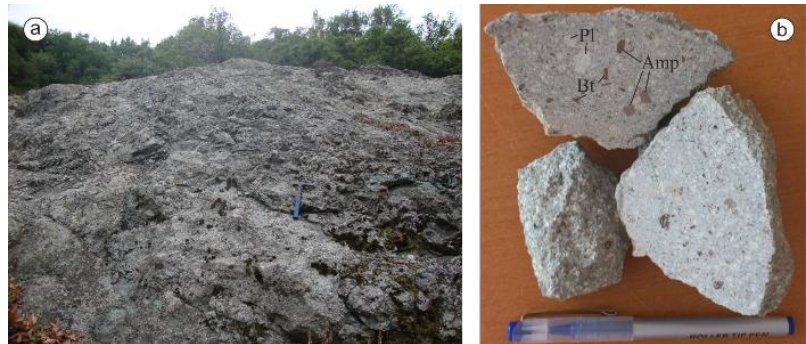

Figure 4. (a) Massive lava of Beyçayır volcanic, (b) Dacitic lava in porphyritic texture (Pl: Plagioclase, Bt: Biotite, Amp: Amphibole).

\section{Kızıldam Volcanics}

These volcanic rocks, which were mentioned as part of Akçaalan and Balıklıçeşme volcanics in previous studies, show wide distribution in the study area. The unit, which consists of basalt, basaltic andesite, volcanoclastics and turbiditic deposits in the Bilaller member, following the Beyçayır volcanics, was first named the Şahinli formation by Dönmez et al. (2005) due to its type locality around Şahinli village. In detailed field and mapping studies, the assemblage which covers approximately $150 \mathrm{~km}^{2}$ of the study area and consists of basalt, basaltic andesite, basaltic trachyandesite composition flow breccia, lava and lahar, was firstly named the Kizıldam volcanics due to different facies mapped in the village of Kizıldam, where the unit is best observed in this study. Kizıldam volcanics present a stratigraphy consisting of lava flows occasionally over flow breccia and lahar flows at the top (Figure 6). 


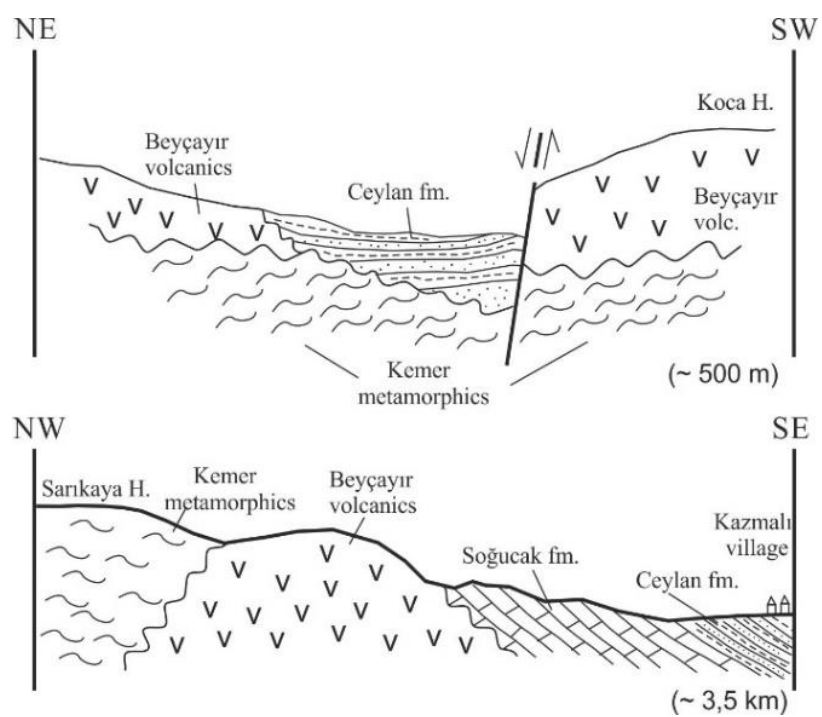

Figure 5. Geological cross sections showing the contact relations of Beyçayır volcanics with basement rock and sedimentary units (Geological cross sections in figures are simplified and generalized sections drawn as a result of field observations showing the lithostratigraphic relations of different lithological units on a plane).

The most prominent and widespread member of the Kizildam volcanics in the study area consists of flow breccias. The most typical outcrops of flow breccia are found in and around Kizildam village (Figure 7a). Flow breccias developed as a result of fragmentation of lava and consist of volcanic blocks of different sizes, gravels and the same type of lava matrix containing these gravels. The size of the gravel varies from approximately $2-3 \mathrm{~cm}$ to large blocks up to meters in size. The blocks have monogenic features. The outer surface of the unit is purplish pink, and when the gravels are broken, it is observed to have dark gray-black color.

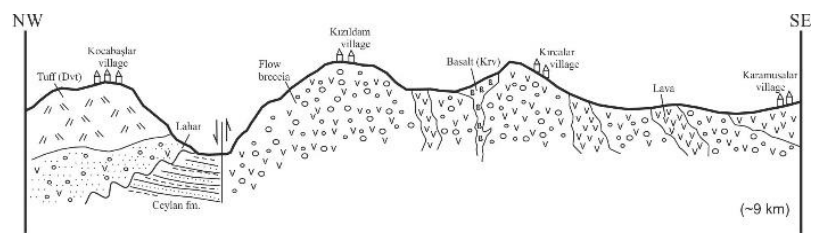

Figure 6. Geological cross section of lava flows of Kizildam volcanics.

Lava streams form at high temperatures. For this reason, hot lavas can maintain magmatic temperatures during movement and for a short time after their settlement. In lavas developed at high temperatures, pink color microliths form as a result of thermal oxidation of iron minerals or dark color microliths due to crystallization of magnetite (or other iron/manganese oxide minerals) (Cas and Wright, 1987). The pink, purple and purple colors observed in flow breccias in the study area are thought to be caused by the oxidation of iron minerals from the settlement at high temperatures.

The lavas that form the Kizıldam volcanics are generally observed above flow breccias or intercalating with them (Figure 7b). They have basaltic trachyandesite composition. Like flow breccias, hot lava flows show a purplish pink color on their outer surfaces due to iron oxidation. Freshly broken surfaces are observed with gray, dark gray and black colors. They mostly present a massive structure, while irregular fracture and crack systems are common.

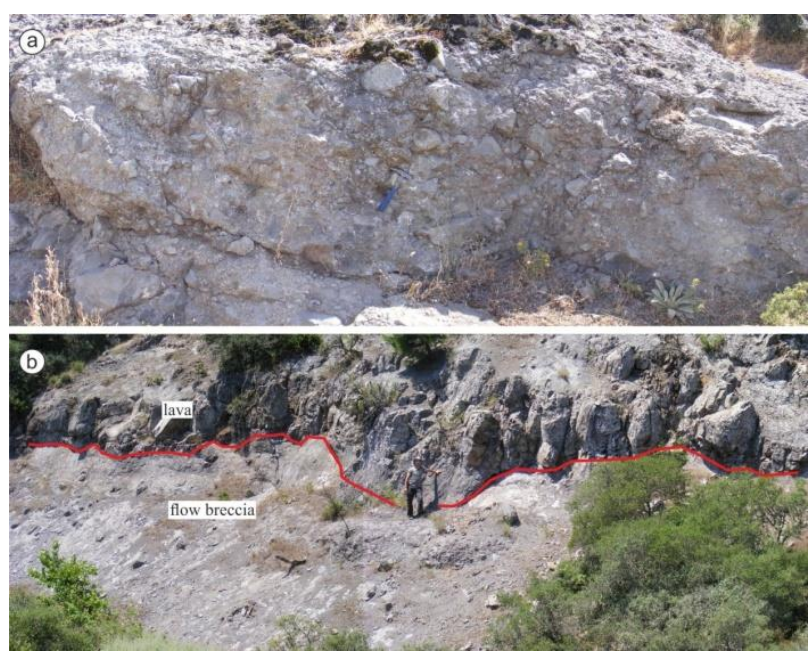

Figure 7. (a) Flow breccias of Kizıldam volcanics (UTM Zone 35: 486258 E, 4455928 N), (b) Lavas (UTM: 491775 E, $4450601 \mathrm{~N})$.

The lahar flows of the K1zıldam volcanics are composed of gravel and blocky mud streams of volcanic origin. The size of the grains transported varies from volcanic ash to block size. It is poorly sorted and no stratification was found. Block and sludge ratio varies from place to place. The size of gravel and blocks varies from $5 \mathrm{~cm}$ to $20 \mathrm{~cm}$. Gravel and blocks generally have the same composition and present monogenic properties. These monogenetic ash-block flows probably developed due to lava dome subsidence. The most important feature in separating these flows from flow breccias is that the material between the blocks consists of free ash and sludge content. However, in flow breccia, the lava flow that does not dissociate between gravel and blocks forms integrating with the clasts.

\section{Oligocene Magmatic Rocks Çamyayla Pluton}

Çamyayla Pluton is a plutonic rock assemblage with approximately $63 \mathrm{~km}^{2}$, which accompanied Oligocene volcanism in the western part of the Biga Peninsula. (Söylemezoğlu, 2009). Plutonic rocks observed in the southwestern corner of the study area have granite and quartz-monzonite composition. Granite and quartz monzonite rocks consist of gray-dark gray holocrystalline, medium-coarse grained, quartz, alkali feldspar, plagioclase with mafic minerals of amphibole and biotite phenocrystals.

\section{Dededă Volcanics}

The volcanic products observed around and west of Dededağ, which constitute one of the most prominent elevations in the study area $(719 \mathrm{~m})$, were evaluated within the Paleocene-Eocene Akçaalan volcanics and the Eocene Balıklıçeşme volcanics in previous studies. Dönmez et al. (2005) studied volcanic products consisting of andesitic, rhyolitic lava and pyroclastics as Middle-Late Eocene Dededağ volcanics coeval with the 
Ceylan formation in the Upper Eocene. In the study area, the Dededağ volcanics contain different volcanic facies, which consist of the following units from bottom to top:

- Lava flows mostly with trachydacite and rhyolitic compositions,

- Rhyolitic compound pyroclastics,

- Layered tuff and flow units observed with dacite composition on top.

The altered outer surfaces and the broken clean surfaces of the trachydacitic lavas belonging to the Dededag volcanics are gray and light gray, respectively (Figure $8 \mathrm{a}$ ). Silicification is very common in these lavas (Figure $8 b$ ). Dededağ, which is the most intense and common part of silicification, looks like a silicified dome. The clean surfaces of the yellowish-brown colored trachydacite lava surrounding the north and south of Dededağ are light gray. Regular joint and crack systems developed (Figure 8c). It is also possible to observe columnar cooling structures (Figure 8d).

The rhyolite lava and tuffs belonging to the Dededağ volcanics are widely observed in the western part of Dededağ and in the north and southeast of the Koruobas1 neighborhood. Porphyritic and locally aphanitic textured rhyolite lavas are observed with cream, beige and yellowish colors (Figure 8e). In addition, it is possible to see alteration such as kaolinization, chloritization and silicification around lavas. Spherulites are present in rhyolites, and they probably formed from devitrified spherulitization of volcanic glass during sudden cooling of the lava. In addition, advanced ferrous and clayey alteration is observed in rhyolitic lavas between Koruobası and Kundakçılar neighborhoods (Figure 8f). There are two mines in the study area, which operate in rhyolitic lavas, where mineralization is most common in the Tesbih stream, north of Yumrutaş Tepe. Chalcopyrite, malachite and rarely galena and sphalerite are observed as ore minerals in these mines.

The tuffs of the Dededağ volcanics with rhyolite composition are light green, chloritization is very common, they have massive structure with irregular abundant fracture and crack systems, forming pyroclastic products containing $2-15 \mathrm{~cm}$ lithic fragments (Figure $8 \mathrm{~g}$ ). Tuffs and lavas in the study area constitute volcanic products directly associated with economically important mineralization in the region. While dense mineralization is seen in rhyolitic lavas, massive rhyolitic tuffs contain disseminated pyrite and rarely disseminated and fracturefill chalcopyrite mineralization.

Volcanic products consisting of rhyolitic tuffs and lavas observed in the Koru stream valley and south of Karaömerler village in the study area, as well as dacitic layered tuff and epiclastic flow units were first studied by Dönmez et al. (2005) as the Korudere ignimbrite member belonging to the Dededağ volcanics. In this study, dacitic tuffs, which are stratified and observed with different erosional forms, especially in the southeast of Karaömerler village, are considered as dacitic pyroclastic products located at the upper level of the Dededağ volcanoes in line with detailed mineralogical and petrographic studies, rather than named ignimbrite. Tuffs can be seen as crystalline or lithic or even intercalated with each other in the vicinity of Dededağ. Moving away from this volcanic environment, tuffs are observed to be vitric. They generally show light green color, layered and less hollow structure. It is possible to find green colored chlorites, clay and zeolite minerals in its cavities. Layers can be observed with different thicknesses from $1 \mathrm{~cm}$ to meters. Quartz, plagioclase and biotite crystals can be visually distinguished in crystalline tuffs.
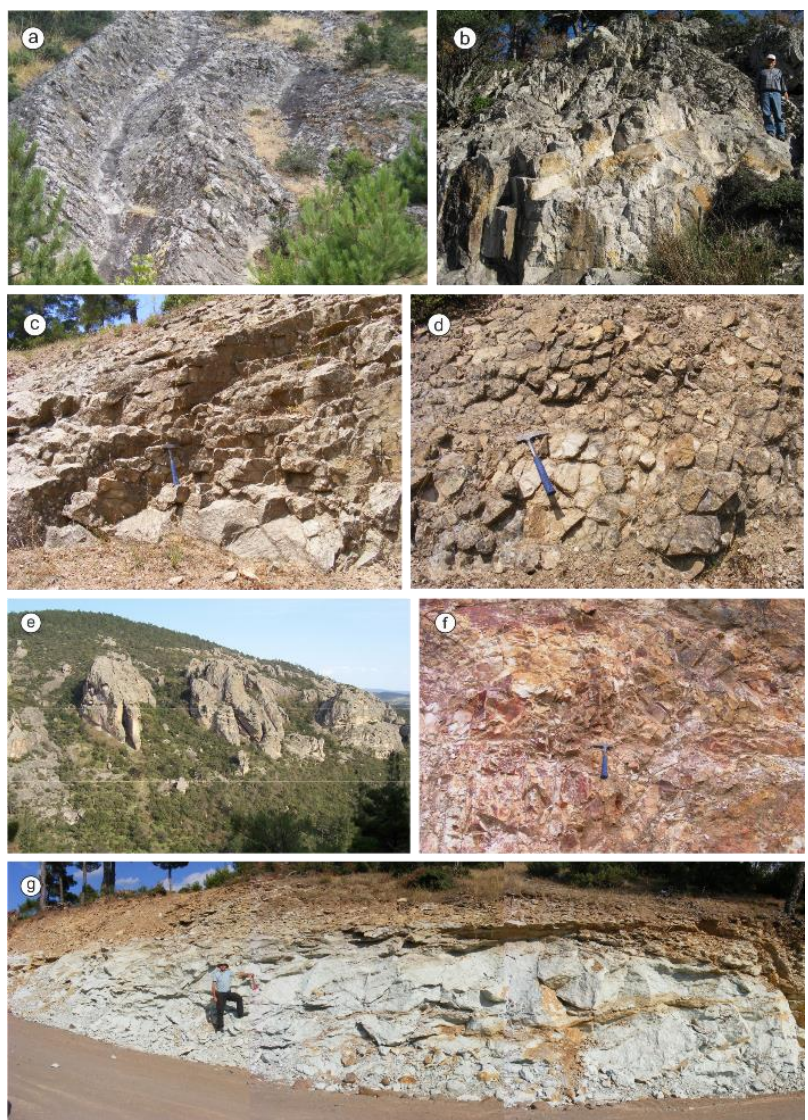

Figure 8. (a) Trachydacitic lavas belonging to the Dededağ volcanics (UTM Zone 35: 483485 E,4452732 N), (b) Silicified trachydacite lavas (UTM: 484285 E, $4451766 \mathrm{~N}$ ), (c-d) Joint-crack systems and columnar cooling structures observed in lavas (UTM: 484488 E, $4450834 \mathrm{~N}$ ), (e) General view of rhyolite lavas (UTM: 478614 E, 4452587 N), (f) Iron oxidation and clayey alteration observed in rhyolite lavas (UTM: $484958 \mathrm{E}$, $4449477 \mathrm{~N}),(\mathrm{g})$ Massive rhyolitic tuffs belonging to the Dededağ volcanics (UTM: $480384 \mathrm{E}, 4450264 \mathrm{~N}$ ).

South of Çamyurt village, tuff outcrops in the Uludere valley are observed as crystalline and lithic tuff alternations. While thin to medium bedding is observed in crystalline tuffs, lytic tuffs are seen as slightly layered or massive.

The vitric tuffs in the southeast of tKazmalı village near the study area were identified as the Kazmalı tuff member by Dönmez et al. (2005) and were observed as intercalated with the turbiditic sediments of the Ceylan formation. In this study, these vitric tuffs are considered together with dacitic tuffs of Dededağ volcanics. It is 
thought that these tuffs constitute the continuation of a pyroclastic flow process. While Dededağ and its surrounding layered tuff products, where Dededağ volcanism took place, have crystalline and lithic fragments, thinner and smaller material may have been transported by air away from the volcanic environment. In addition, considering the effect of the aqueous environment of that period, the coarse particles in the pyroclastic materials carried by water would have moved closer to the region where the volcanism occurred, and the glassy particles would have been transported farther due to their light density. Indicators of this may include the approximate bedding positions in the stratified dacitic tuffs from the village of Kocabaşlar in the northwest corner of the study area, the decrease in grain size and the transition of crystal-lithic tuffs to vitric tuffs.

Epiclastic flow units intercalated with layered dacitic tuffs at the upper level of Dededağ volcanism are observed in Kirazoluk stream, east of Karaömerler village. In addition, together with tuffs, they developed erosional weathering structures similar to fairy chimneys in this region (Figures 9a and 9b).

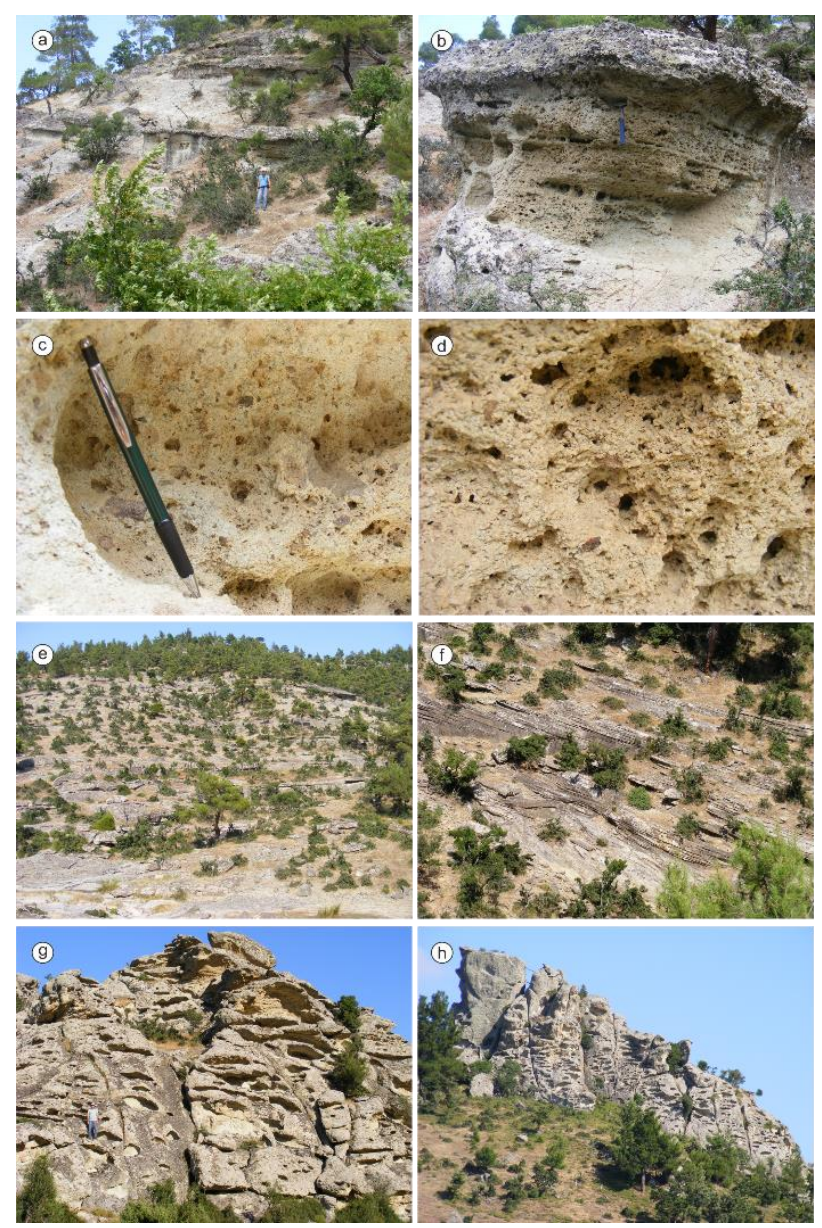

Figure 9. (a-b) Erosional weathering structures observed in the upper levels of the Dededag volcanics, (c-d) Epiclastic flow unit, (e-f) Dacitic bedded tuffs (UTM Zone 35: 483215 E, $4454332 \mathrm{~N}$ ), (g-h) Tafoni observed on tuffs belonging to the Dededag volcanics (UTM: 480726 E, 4454973 N).

There is a tuff level in the upper parts and a weak epiclastic level just below it, where disintegration occurs easily and is not well anchored. When this level is examined closely, it contains abundant plagioclase minerals that can be easily separated and detached from each other and lytic rock fragments of different sizes between $0-5 \mathrm{~cm}$ (Figures $9 \mathrm{c}$ and $9 \mathrm{~d}$ ). There is no pumice content in this material. In addition, the presence of carbonate cement indicates that its formation occurred in an aquatic environment containing carbonate solution. The yellowish cream-colored unit is light green when broken. Large and small cavity ratios are quite high in these sedimentary levels due to easy separation. No cavities are observed in the upper tuff levels. The thickness of the epiclastic flow units between tuff layers varies between 50 and $150 \mathrm{~cm}$. Moving further south from Kirazoluk stream, this level disappears and passes back to thin layered tuff levels (Figures 9e and 9f). No epiclastic flow units and structures were encountered in the environment where dacitic tuffs were observed in the study area and in any other area where they outcrop.

West of Karaömerler village, along the Katran stream valley, the dacitic tuffs without stratification show interesting forms of erosion, i.e. tafoni (Figure $9 \mathrm{~g}$ and 9h). Most tafoni are hollow shapes with an inward sloping wall, ceiling, and a base that make up about $70 \%$ of a full sphere volume. These cavities on the rock surface can have different sizes from $\mathrm{cm}$ to meters. The floor areas are generally flat, but grains detached from the wall and ceiling can be observed to accumulate in cracks and on the floor.

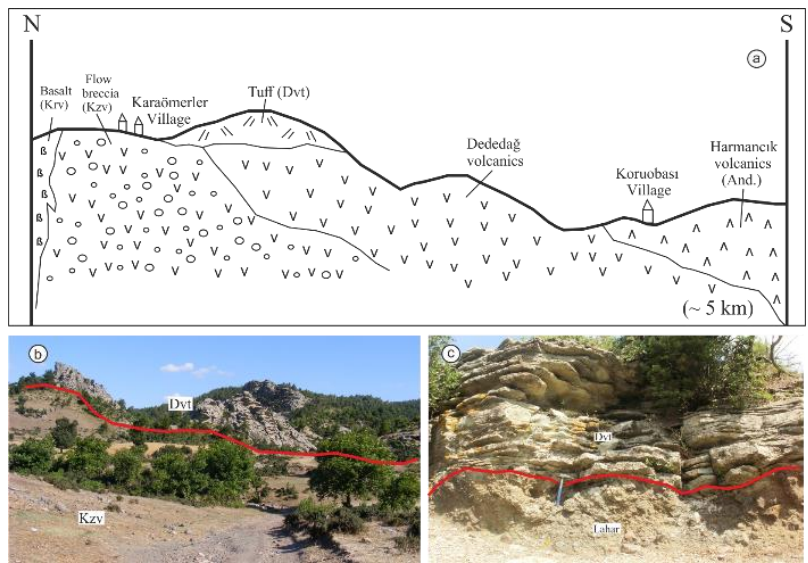

Figure 10. (a) Geological cross section showing the contact relations of the Dededağ volcanics with other volcanic units, (b) Tuffs of Dededağ volcanics observed on Kizildam volcanics (UTM Zone 35: 480640 E, $4455356 \mathrm{~N}$ ), (c) Layered crystalline tuffs on the lahar stream of the Kizidam volcanics (UTM: 482358 E, $4457995 \mathrm{~N})$.

Considering the outcrops of volcanism that continued intermittently since the Eocene, it is possible to see the contact of the lava and tuff units of the Oligocene Dededağ volcanics with the Eocene Kizıldam volcanics in many regions. While Dededağ volcanics observed in the west of the study area are to be covered by Kizildam volcanics in the north, they are overlain by Harmancik volcanics, which represent the last products of volcanism in the region in the south (Figure 10a). West of Karaömerler village, dacitic tuffs belonging to the 
Dededağ volcanics with different erosional surfaces are located on flow breccias of Kizildam volcanics (Figure $10 \mathrm{~b})$. South of Kocabaşlar village, layered dacitic tuffs are unconformably observed above lahar flows of Kizildam volcanics on the southern slope of Dede hill (Figure 10c).

\section{Kircalar Volcanics}

When the basaltic andesite and basalt volcanic rocks belonging to the Kurcalar volcanics are compared with the studies conducted by Ercan et al. (1995) and Yilmaz, (2004), they can be regarded as equivalent to some of the Kirazlı volcanics. Dönmez et al. (2005) refer to these rocks with basic characteristics as the Şahinli formation within the Eocene volcanics. In addition, there are lithological similarities with the Erdağ volcanics outside the study area. They form layered crystalline tuffs on the lahar stream of the Kizıldam volcanics. In the study conducted by Söylemezoğlu (2009) in the region close to the study area, basaltic andesite rocks similar to this volcanic unit were discussed under the name of Dedeler basaltic andesite. For rocks with basalt and basaltic andesite compositions, the name Kurcalar volcanics is used in this study because of the most common outcrops around Kircalar village.
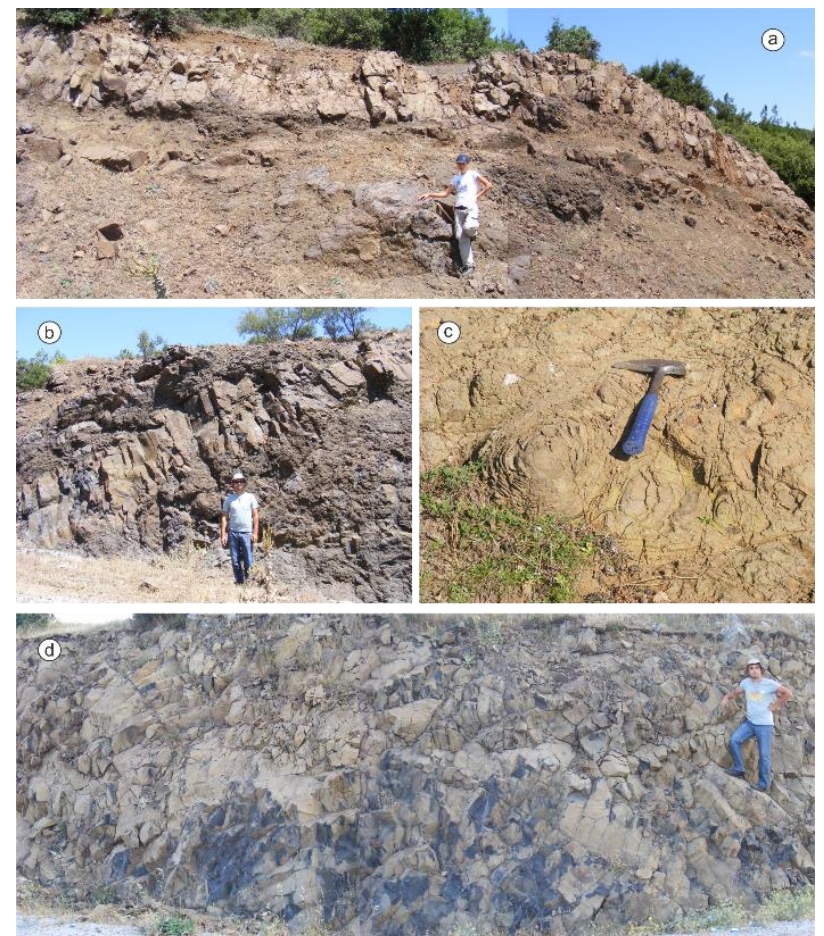

Figure 11. (a-b) Sil and dyke observed in the study area of the Kircalar volcanics (UTM Zone 35: 479103 E, $4459023 \mathrm{~N})$, (c) Their appearance in the form of onion skin-type disintegration (exfoliation) (UTM: $482143 \mathrm{E}$, $4461100 \mathrm{~N}$ ), (d) Basaltic andesites belonging to the Kircalar volcanics (UTM: 495176 E, 4454175 N).

In the study area, the surfaces of this unit were mapped in many different areas. In addition to their partially large outcrops, they also form meter-sized dykes in many areas.

Kircalar volcanics are mostly composed of basaltic andesite and volcanic rocks with lower basalt composition. These lavas have different formation patterns in their outcrops in the field. They are generally observed as sills developed parallel to the volcanic flow in the flow breccia of Kizıldam volcanics, feeder dykes emplaced by cutting flow breccias in Figures 11a and $11 \mathrm{~b}$, massive flows and onion skin-type disintegration in Figure 11c. Clean surfaces of basic lava are black with yellowish-brown altering color observed (Figure 11d). It has mostly aphanitic texture and black colored paste. However, large pyroxene phenocrysts in black paste can be distinguished by the naked eye in some samples. In areas where massive lava flows are observed, abundant fracture and crack systems developed. Columnar cooling structures are also found in some areas.

The contact relations of basic lavas belonging to Kircalar volcanics are mostly seen with Kizildam volcanics but also with dacitic tuffs of Dededağ volcanics in the study area. The Kurcalar volcanites were observed to cut the flow breccias of Kizildam volcanics in many areas (Figure 12a). Although not everywhere, an orangebrownish burning zone was observed in outcrops east of the village of Karaömerler and at the contact with the Kizildam volcanics.

On the village road between Şahinli and Karaömerler, the Ceylan formation and the Kizildam volcanics located on it are cut by basalt dykes of the Kurcalar volcanics in small outcrops in the Uludere valley. In addition, they were emplaced by cutting stratified dacitic tuffs belonging to the Dededağ volcanics together with the Kizıldam volcanics south of Çamyurt village (Figure 12b).

\section{Harmancık Volcanics}

A detailed study of these volcanic rocks located in the south of the study area was not carried out before. In the mapping studies carried out by Bingöl et al. (1975) and General Directorate of Mineral Research and Exploration in Turkey, Harmanc1k Volcanics were distinguished as Oligocene andesite, ignimbrite and tuff. These volcanic rocks are equivalent to some of the Kirazlı volcanics in the studies by Ercan et al. (1995). Bozkaya and Gökçe (2009) mentioned andesite rocks in the Koruobası district as Middle Eocene Akçaalan andesite in their studies. Söylemezoğlu (2009) named andesite, trachyandesite, rhyolite, rhyodacite, dacite and related pyroclastic rocks as the Dededağ formation in the region including Harmancık village around and north of Çamyayla pluton.

The rhyolite, trachydacite, andesite and basaltic trachyandesite rocks, studied and mapped in detail in this study, are named the Harmancik volcanics due to their widespread distribution around Harmanc1k village. The Harmanc1k volcanics seen in the south of the study area have different observational features to the Late Eocene Kizıldam volcanics and the Early Oligocene Dededağ volcanics. They have different compositions from rhyolite to basaltic trachyandesite. 


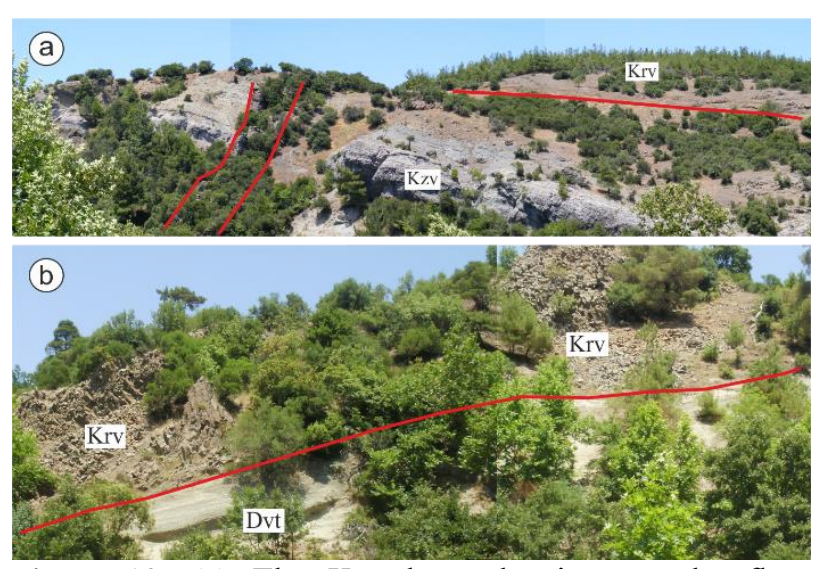

Figure 12. (a) The Kircalar volcanics cut the flow breccias of Kizıldam volcanics and flow over them (UTM Zone 35: 479155 D, $4458160 \mathrm{~K}$ ), (b) Basalt lavas cutting dacitic tuffs (UTM: $486652 \mathrm{E}, 4457968 \mathrm{~N}$ ).

Rhyolitic lavas belonging to the Harmancık volcanics are the most common volcanic product observed north and east of Harmancik village. The altered outer surfaces of rhyolites are greenish cream colored, and they are seen to have white, gray and light green colors on the freshly fractured surfaces. They generally have aphanitic texture; phenocrysts are very fine-grained and consist of plagioclase and quartz minerals. Rhyolitic lavas do not contain any mineralization like the rhyolitic lavas described in the Dededağ volcanics. With these aspects, it is not difficult to distinguish these two lavas with the same composition. A distinct flow direction from east to west is observed in these lavas (Figure 13a).
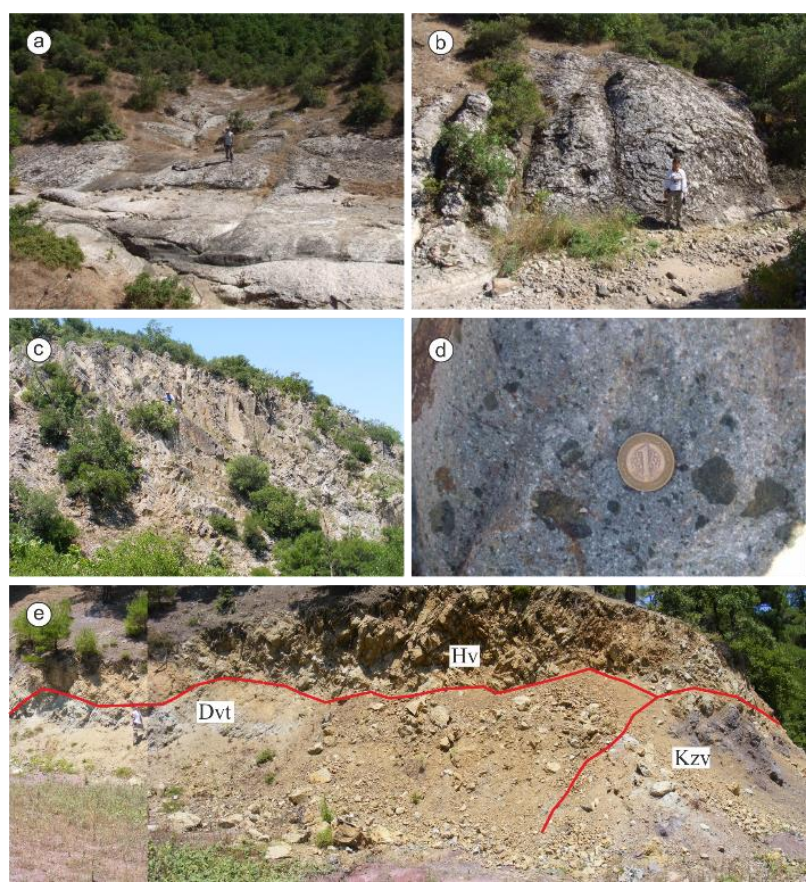

Figure 13. (a) Rhyolite flow of Harmancik volcanics (UTM Zone 35: 482811 E, 4445641 N), (b) Rhyolite dome (UTM: 483072 E, 4445981 N), (c) Abundant fractured and fractured trachydacite lavas belonging to the Harmancik volcanics (UTM: 484031 E, / 4445133 $\mathrm{N})$, (d) trakidasit lavlar içinde gözlenen bazik magma ksenolitleri, (e) Kızıldam volcanics and Harmancık volcanics located on tuffs belonging to Dededağ volcanics (UTM: $484985 \mathrm{E}, 4446395 \mathrm{~N}$ ).

Table 1. General mineralogical and petrographical characteristics of the magmatic rocks in Dededağ area.

\begin{tabular}{|c|c|c|c|}
\hline & Texture & Mineralogy & Rock name \\
\hline \multicolumn{4}{|l|}{ Granitoids } \\
\hline Laledağ granitoid & holocrystalline, hypidiomorphic & $\begin{array}{l}\text { plagioclase, quartz, orthoclase, } \\
\text { amphibole (hornblende) and biotite. } \\
\text { Sphene and zircon as secondary mineral }\end{array}$ & granodiorite \\
\hline Çamyayla pluton & holocrystalline porphyritic & $\begin{array}{l}\text { plagioclass, alkali feldspar, quartz, } \\
\text { hornblende and biotite }\end{array}$ & granite \\
\hline \multicolumn{4}{|l|}{ Volcanic rocks } \\
\hline Beyçayır volcanics & hypocrystalline, porphyritic & $\begin{array}{l}\text { plagioclass, hornblende, biotite and } \\
\text { quartz }\end{array}$ & dacite and andesite \\
\hline Kizildam volcanics & $\begin{array}{l}\text { hypocrystalline, porphyritic, } \\
\text { aphanitic porphyritic, İntersertal, } \\
\text { pilotaxic and hyalopilitic }\end{array}$ & $\begin{array}{l}\text { plagioclass and pyroxene, sanidine, } \\
\text { chlorite and zeoliteas secondary mineral }\end{array}$ & $\begin{array}{l}\text { trachybasalt, basaltic andesite } \\
\text { and basaltic trachyandesite }\end{array}$ \\
\hline Dededağ volcanics & $\begin{array}{l}\text { hypocrystalline porphyritic or hyalo- } \\
\text { porphyritic }\end{array}$ & $\begin{array}{l}\text { Plagioclass, sanidine, quartz, biotite and } \\
\text { hornblende, } \\
\text { chloriteas secondary mineral, } \\
\text { sericitization in plagioclass minerals }\end{array}$ & trachydacite, dacite and rhyolite \\
\hline Kircalar volcanics & $\begin{array}{l}\text { hypocrystalline porphyritic, } \\
\text { intersertal and / or trachytic }\end{array}$ & $\begin{array}{l}\text { plagioclase, pyroxene, olivine and } \\
\text { opaque minerals } \\
\text { chlorite and sericiteas secondary mineral }\end{array}$ & basalt and basaltic andesite \\
\hline Harmancık volcanics & $\begin{array}{l}\text { hypocrystalline porphyritic, } \\
\text { hyalopilitic, intersertal or pilotaxic }\end{array}$ & $\begin{array}{l}\text { plagioclase, hornblende, pyroxene, } \\
\text { sanidine, quartz } \\
\text { claying and chloritization in matrix }\end{array}$ & $\begin{array}{l}\text { basaltic trachyandesit, basaltic } \\
\text { andesite, trachyandesite, andesite, } \\
\text { trachydacite and rhyolite }\end{array}$ \\
\hline
\end{tabular}

This unit also takes the form of small domes (Figure 13b). Trachydacitic lavas can be easily distinguished from rhyolitic lavas with abundant fractures, and occasionally massive and hard structures. These lavas are observed to have brownish gray colors on their altered surfaces (Figure 13c).
The unit is observed to have shades of gray, green and pink on clean surfaces. It has porphyritic texture and although feldspar minerals are visible, very small and thin looking biotite minerals cannot be clearly seen on the rock. In addition, these volcanic products contain a remarkable amount of magma xenoliths with sizes 
varying between $0.5-5 \mathrm{~cm}$ and dark gray-black color (Figure 13d). These xenoliths are basic in composition and some have a green color, possibly due to chloritization. The basic and intermediate rocks of the Harmanc1k volcanics crop out in NE-SW direction in the southwest of the study area. The basic rocks of the Harmanckk volcanics, the Dededağ volcanics and the Kizıldam volcanics have inconsistent contacts (Figure $13 \mathrm{e})$.

\section{Petrography}

Magmatic rocks in the study area were classified according to their lithological properties, and main rock types, mineralogical compositions and textural features of magmatic rocks are summarized in Table 1.

In thin section samples of plutonic rocks, holocrystalline, hypidiomorphic texture consisting of medium-coarse crystals was observed. Mineral compositions consist of plagioclase, quartz, orthoclase, amphibole (hornblende) and biotite minerals (Figure 14a and 14b). The ratio of plagioclase minerals is effective in distinguishing granite and granodiorite. Epidote, sphene and zircon were present as secondary minerals.

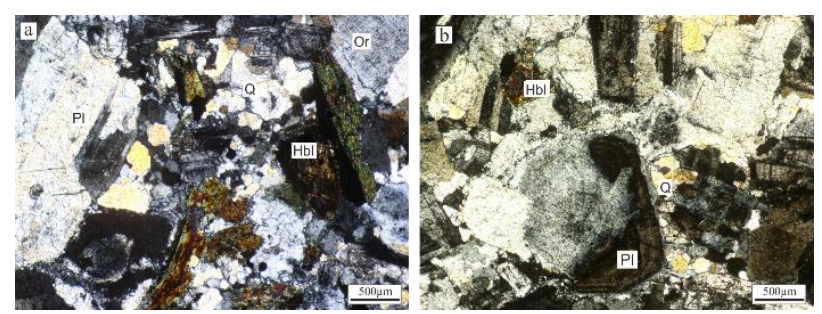

Figure 14. (a) Mineralogical compositions of Laledag granodiorite, (b) Mineralogical compositions of Çamyayla granite (Pl; Plagioclase, Hbl; Hornblende, Or; Orthoclase, Q; Quartz).

Beyçayır volcanics, one of the Eocene volcanics, have hypocrystalline, porphyritic texture, and plagioclase, hornblende, biotite and quartz composition. (Figure 15a). Dacite rocks in thin sections differ from andesites with the presence of quartz minerals. The basic composition of Kizıldam volcanics has aphanitic porphyritic texture. The main minerals in trachybasalt, basaltic and andesite rock fragments are plagioclase and pyroxene (Figure 15b). Chlorite and zeolite are commonly found in thin sections as secondary minerals.
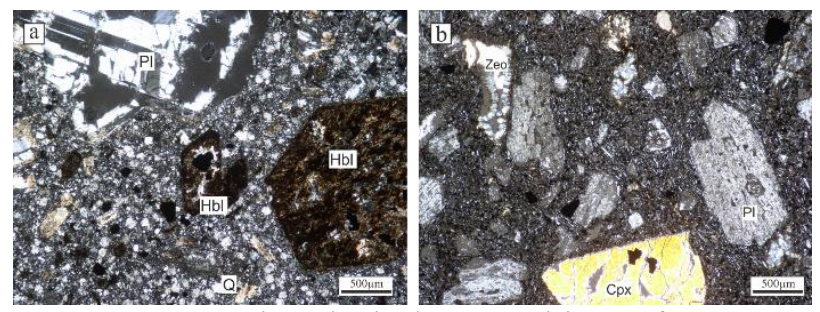

Figure 15. (a) Mineralogical compositions of Beyçayır, (b) Mineralogical compositions of Kizıldam volcanics (Pl; Plagioclase, Hbl; Hornblende, Cpx; Clinopyroxene, Q; Quartz, Zeo; Zeolite).

Oligocene volcanics in the study area consist of very different rock components varying from basalt to rhyolite. Dededağ volcanics with acidic composition of trachydacite, dacite and rhyolite show hypocrystalline porphyritic or hyalo-porphyritic textures (Figure 16a and $16 \mathrm{~b})$. Sericitization due to alteration is observed in some plagioclase phenocrysts. In addition, devitrified volcanic glass forms radial spherulites in some of the rhyolitic lava samples. Rocks belonging to Kurcalar volcanics consist of basalt and basaltic andesites. Major minerals are plagioclase, pyroxene, olivine and opaque minerals. (Figure 16c and 16d). In addition, chlorite and sericite form secondary alteration minerals in basaltic andesite rocks. Unlike all other volcanic units, Harmancık volcanics contain rocks with both acidic and basic characteristics. From basic to acidic, these rocks consist of basaltic trachyandesite, basaltic andesite, trachyandesite, andesite, trachydacite and rhyolite. These rocks, which are mostly observed to have hypocrystalline porphyric texture, contain plagioclase, hornblende, pyroxene, sanidine and quartz minerals with different ratios depending on their composition (Figure $16 \mathrm{e}$ and 16f).

\section{Major Element Geochemistry}

In order to determine the geochemical characteristics of the magmatic rocks in the region, the classification diagrams suggested by some researchers were used. The geochemical studies of Eocene and Oligocene magmatic rocks were carried out using the values calculated for geochemical results of the analyzed samples on an anhydrous basis (LOI: Loss-on-ignition, proportional to the major elements) (Table 2).
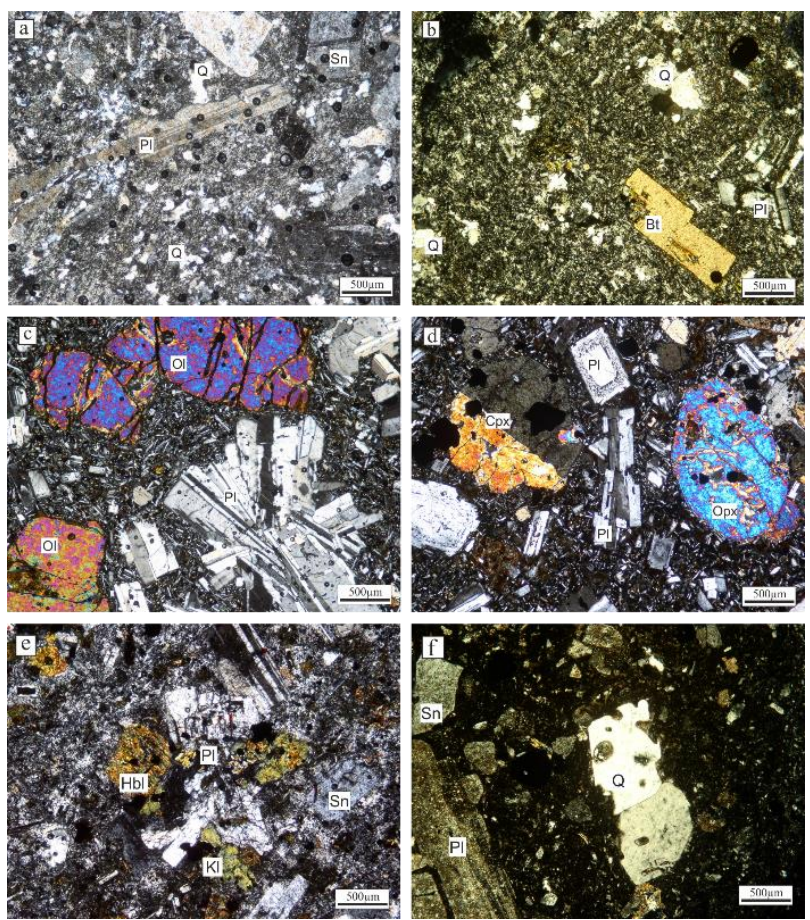

Figure 16. (a) Trachydacite of Dededağ volcanic, (b) Rhyolite of Dededağ volcanic, (c-d) Basalt of Kircalar volcanics, (e) Basaltic trachyandesite of Harmancik volcanic, (f) Trachydacite of Harmancik volcanics (Plg; Plagioclase, San; Sanidine, Hbl; Hornblende, Bt; Biotite, Ol; Olivine, Cpx; Clinopyroxene, Opx; Orthopyroxene, Q; Quartz, Kl; Clorite). 


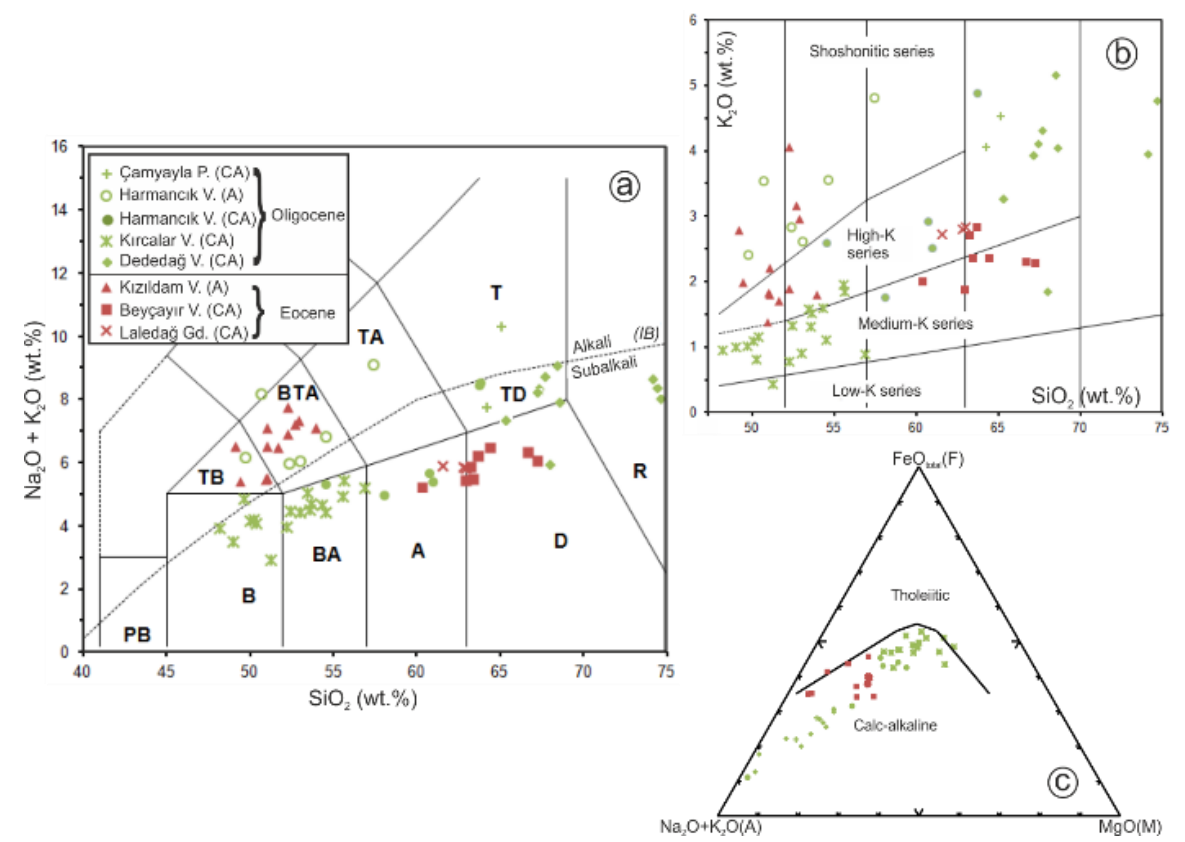

Figure 17. Geochemical classification of the Eocene-Oligocene volcanic rocks in the Dededag area (a) TAS diagram; the dashed line separating alkaline series from subalkaline series, (b) $\mathrm{K}_{2} \mathrm{O}$ vs $\mathrm{SiO}_{2}$ diagram, (Peccerillo ve Taylor, 1976), (c) AFM diagram.

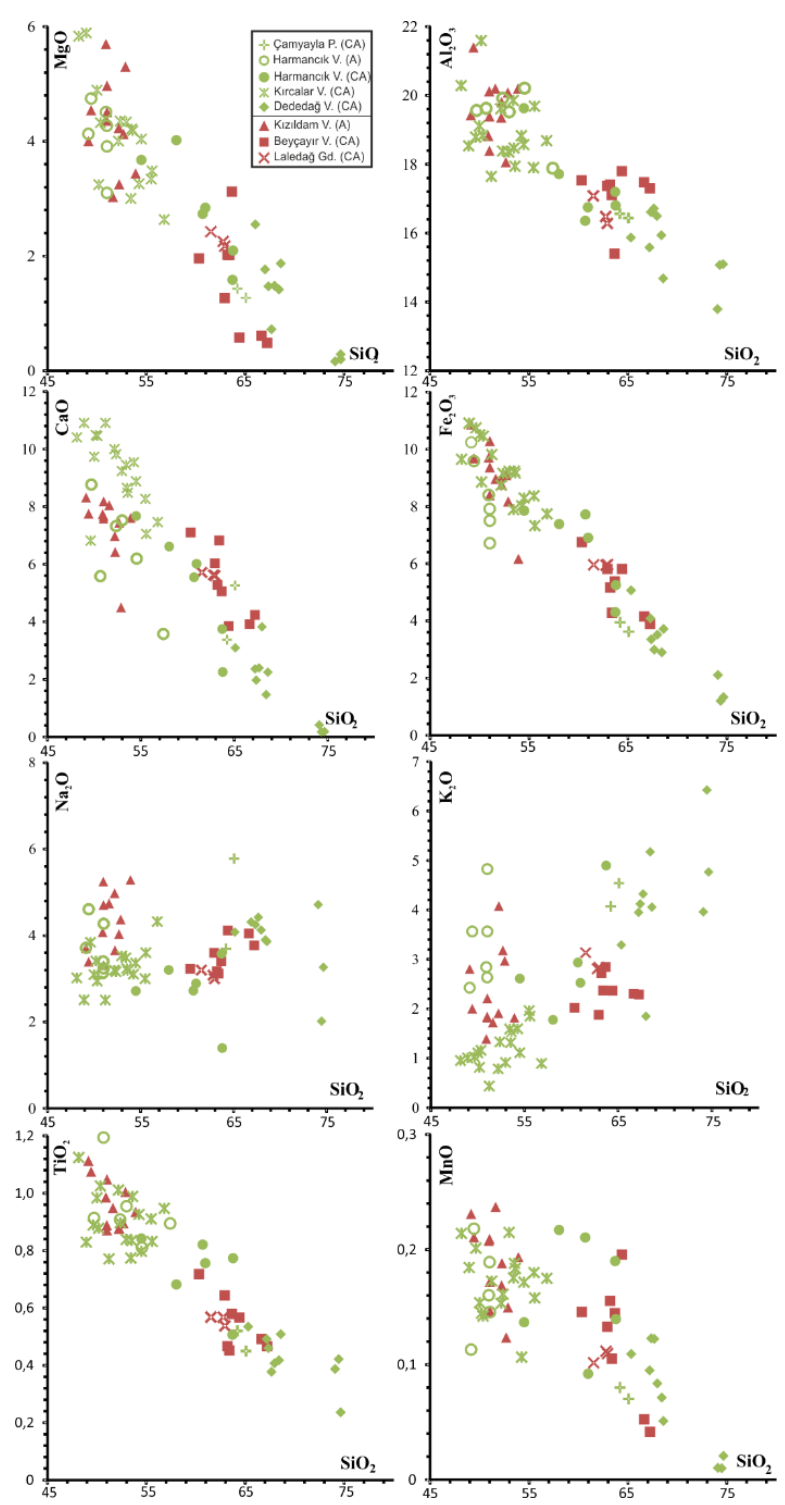

Figure 18. Major element Harker diagrams for Eocene-Oligocene magmatic rocks. 
The most trends on these variation diagrams are a result of magma mixing processes. The mixing of magma may originate from two magmas. It may occur from the addition and/or separation of solid phases during contamination or fractional crystallization. It may also occur with mixing due to the addition of melts during partial melting (Rollinson, 1993).

The samples of Dededağ volcanics cluster in trachydacite, dacite and rhyolite area. Kircalar volcanics, although mostly basaltic andesite, also contain rocks with basalt composition. The Harmancik volcanics, on the other hand, contain units with different characteristics, including basaltic andesite, basaltic trachyandesite rocks, andesite and trachydacite rocks. The aim was to determine the alkali-subalkali characteristics of the volcanic series with the alkalisubalkali line proposed by Irvine and Baragar (1971) on the TAS diagram (Figure 17a). According to this line of separation, the samples of Laledag granodiorite and Beyçayır volcanics belonging to the Eocene period remain in the subalkali area and the Kizildam volcanics plot in the alkaline area. All of the samples from the Dededağ and Kurcalar volcanics, and intermediate products of the Harmanc1k volcanics in the Oligocene period remain in the subalkali area and the basic samples plot in the alkaline area.

In Figure 17b, the calc-alkali Beyçayır volcanics from the Eocene period are in the mid-high-K, and the alkaline Kizildam volcanics plot in the high-K shoshonitic series. It is observed that the calc-alkali Dededağ volcanics from the Oligocene period are high$\mathrm{K}$, the Kurcalar volcanites are medium-K, and the Harmancik volcanics are high-K, and the alkaline samples plot in the shoshonitic series. On Irvine and Baragar (1971)'s AFM diagram, the samples of alkaline Kızıldam volcanics and Harmancik volcanics are excluded from this classification. All sub-alkali samples from Laledağ granodiorite, Beyçayır volcanics, Kırcalar volcanics and Harmancik volcanites are located in the calc-alkaline area (Figure 17c).

Harker variation diagrams were used by plotting the major element oxide values of the magmatic rocks in the region in this study, which show the changes occurring in the magma as a result of fractional crystallization (Figure 18). $\mathrm{Al}_{2} \mathrm{O}_{3}, \mathrm{TiO}_{2}$ and $\mathrm{Fe}_{2} \mathrm{O}_{3}$ show linear negative correlation against $\mathrm{SiO}_{2}$ for all volcanics in the diagrams. Although calc-alkaline samples show linear negative correlation on $\mathrm{MgO}$ and $\mathrm{CaO}$ diagrams, fast depletion is observed in a narrow range of $\mathrm{SiO}_{2}$ content in some of the samples belonging to the alkaline Kizıldam volcanics and Harmancik volcanics. There is a positive correlation for both basic rocks and intermediate-acidic rocks of the Eocene and Oligocene for $\mathrm{Na}_{2} \mathrm{O}$ and $\mathrm{K}_{2} \mathrm{O}$. While there is a rapid decrease in $\mathrm{MnO}$ for Eocene and Oligocene basic rocks, the decrease against increasing $\mathrm{SiO}_{2}$ for intermediate-acidic rocks occurs only after $\mathrm{SiO}_{2}$ reaches $57-58 \%$. In this way, positive and negative correlations can be explained by the fractional crystallization process. The negative trend for major oxides means that they are increasingly depleted in the magma during the crystallization process and are added to the crystal composition. Due to crystallization of olivine, pyroxene and Ca-rich plagioclase in the first stages of crystallization, the residual magma solution shows depletion in major oxides such as $\mathrm{Fe}_{2} \mathrm{O}_{3}, \mathrm{MgO}$ and $\mathrm{CaO}$ for all volcanic units. The sudden decrease in $\mathrm{Al}_{2} \mathrm{O}_{3}$ can be explained by the participation of feldspar, amphibole and biotite minerals in the crystallization process as the magma composition becomes more intermediate. In the later stages, crystallization of amphibole and biotite results in gradual decreases in the concentrations of $\mathrm{TiO}_{2}$ and $\mathrm{MnO}$ in the melt along with ferromagnesian elements. There is a tendency to incorporate $\mathrm{Na}_{2} \mathrm{O}$ and $\mathrm{K}_{2} \mathrm{O}$ in alkali feldspar, Na-plagioclase, mica and amphibole minerals. They show an increasing trend for all volcanic units as they remain in melt until the last stages of crystallization.

\section{Discussion and Conclusion}

During the post-collisional Eocene magmatism in the Biga Peninsula, plutonism and volcanism occurred together. Throughout the Oligocene period that followed, this magmatism continued to become more intense. In this study carried out in Dededağ and surroundings, magmatic units can be divided into 6 different units lithostratigraphically in the region where metamorphic bedrock, magmatic and sedimentary rock assemblages are observed together. These are the Laledağ granodiorite, Beyçayır and Kızıldam volcanics, Dededağ volcanics, Kurcalar volcanics and Harmancık volcanics. As a result of mineralogical-petrographic investigations, the Laledağ intrusive is a stock with granodiorite composition. Beyçayır volcanics are mostly composed of rocks with dacitic and andesitic composition and intermediate character. Kizıldam volcanics are composed of basic rock lithologies with basaltic trachyandesite, trachybasalt compositions. Dededağ volcanics contain intermediate-acidic dacite and rhyolite composition lava and pyroclastic products. Kurcalar volcanics consist of basic basalt and basaltic andesite rocks. It was determined that the Harmancik volcanics have a wide range of compositions ranging from basalt to rhyolite. These results are consistent with the TAS diagram plotted using major oxide elements. The major oxide element analysis enables differentiation of two different volcanic products with calc-alkaline (Beyçayır, Dededağ, Kircalar, Harmancık volcanics) and alkaline (basic samples of Kizildam and Harmanc1k volcanics) characteristics in the region.

In all previous studies, Oligocene period volcanism was considered to be a continuation of the calc-alkaline series after the Eocene period. However, in the study area, in volcanic series that continued at short intervals in the Eocene-Oligocene period, the presence of alkaline volcanism in the Oligocene in the Biga Peninsula was observed, as in the Eocene volcanics. These alkaline rocks in the Eocene and Oligocene volcanism do not have the same origin compositionally and originally, except that they are basic in character compared to the 
Table 2. Major element oxide analysis results of Eocene-Oligocene magmatic rocks in the study area (\%)

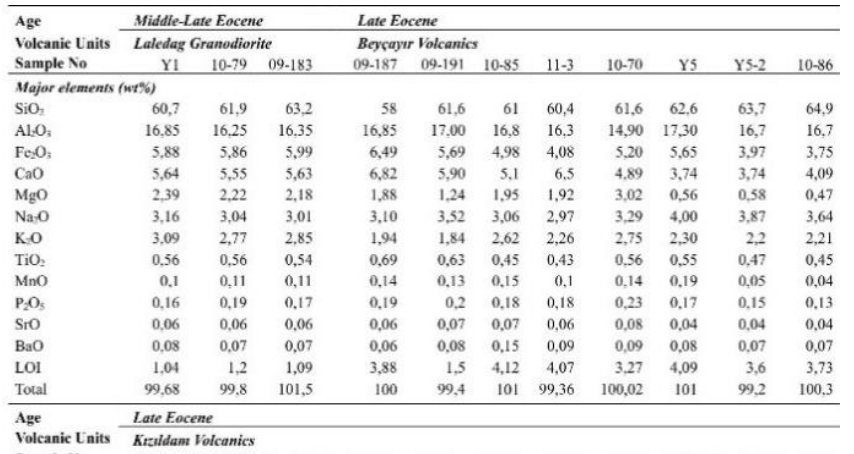

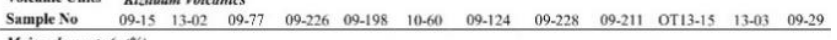
Majar elements (wer\%)

\begin{tabular}{|c|c|c|c|c|c|c|c|c|c|c|c|c|}
\hline $\begin{array}{l}\text { SiO } \\
\text { Sol }\end{array}$ & 46,8 & 46,9 & 49,1 & 48,8 & 47.5 & 48,7 & 50.1 & 49.5 & 51.2 & 49.5 & 50,2 & 50 \\
\hline $\mathrm{Al}=\mathrm{O}_{3}$ & 18,5 & 20,3 & 18,15 & 19,25 & 18,05 & 17,6 & 19,60 & 18,35 & 17,55 & 18,8 & 18,8 & 19 \\
\hline $\mathrm{Fe}_{2} \mathrm{O}_{3}$ & 10,35 & 9,19 & 9,36 & 8,03 & 8,72 & 9,81 & 8,70 & 8,32 & 8,84 & 7,65 & 5,74 & 8,64 \\
\hline $\mathrm{CaO}$ & 7,92 & 7.36 & 7,46 & 7,25 & 7,14 & 7,81 & 7,81 & 6,61 & 7,22 & 4,21 & 7,08 & 6,15 \\
\hline $\mathrm{MgO}$ & 3,81 & 4,31 & 5,49 & 4,17 & 4,2 & 4,74 & 2,94 & 4,01 & 4,01 & 4,96 & 3,2 & 3,11 \\
\hline $\mathrm{Na}=\mathrm{O}$ & 3,53 & 3,22 & 3,93 & 5,02 & 4,38 & 3,16 & 4,60 & 4,72 & 3,92 & 4,09 & 4,92 & 3,5 \\
\hline K॰O & 2,67 & 1.9 & 1.34 & 1,76 & 1.69 & 2.11 & 1,67 & 1,81 & 3,09 & 2,78 & 1,69 & 3,9 \\
\hline $\mathrm{TiO}_{2}$ & 1,06 & 1,02 & 0,95 & 0,85 & 0,81 & 1,0 & 0.92 & 0,83 & 0,87 & 0.94 & 0,87 & 0,84 \\
\hline $\mathrm{MnO}$ & 0,22 & 0,2 & 0.20 & 0,20 & 0,16 & 0,14 & 0.23 & 0,16 & 0,12 & 0,14 & 0.18 & 0.18 \\
\hline $\mathrm{P}_{2} \mathrm{O}_{5}$ & 0,22 & 0.29 & 0.22 & 0,26 & 0.31 & 0,29 & 0,21 & 0,34 & 0,27 & 0,26 & 0.29 & 0.26 \\
\hline SrO & 0,04 & 0,11 & 0,10 & 0,05 & 0,1 & 0,07 & 0,10 & 0,09 & 0,05 & 0,1 & 0,05 & 0,08 \\
\hline $\mathrm{BaO}$ & 0,12 & 0.23 & 0,12 & 0,04 & 0,08 & 0,05 & 0.16 & 0,08 & 0,04 & 0,2 & 0,08 & 0,08 \\
\hline LOI & 4,74 & 3.86 & 3,97 & 4,23 & 4,6 & 4.19 & 3,62 & 4,3 & 2,92 & 4.39 & 4,13 & 3,19 \\
\hline Total & 99,98 & 98,76 & 100,4 & 99,91 & 97,7 & 99,6 & 100,66 & 99,1 & 100,1 & 98 & 97,23 & 98,9 \\
\hline
\end{tabular}

\begin{tabular}{ll}
\hline Age & Early Oligocene \\
Volcanic Units & Dededag Volcanic
\end{tabular}

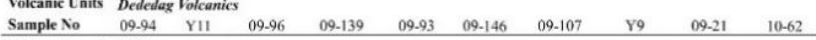

$\begin{array}{rrrrrrrrrrr}\mathrm{SiO}_{2} & 65,9 & 66,4 & 67,2 & 67,5 & 72,7 & 65,1 & 72,8 & 64,4 & 60,5 & 73,6 \\ \mathrm{ALO}_{3} & 16,25 & 16,40 & 15,65 & 14,45 & 14,7 & 15,80 & 13,55 & 14,9 & 14,65 & 14,90\end{array}$ $\begin{array}{lrrrrrrrrrr}\mathrm{Al}_{20} \mathrm{O}_{3} & 16,25 & 16,40 & 15,65 & 14,45 & 14,7 & 15,80 & 13,55 & 14,9 & 14,65 & 14,90 \\ \mathrm{Fe}_{2} \mathrm{O}_{3} & 3,28 & 2,94 & 2,85 & 3,66 & 1,3 & 3,37 & 2,07 & 3,91 & 4,68 & 1,17\end{array}$ $\begin{array}{lllllllllll}\mathrm{Fe}_{2} \mathrm{O}_{3} & 3,28 & 2,94 & 2,85 & 3,66 & 1,3 & 3,37 & 2,07 & 3,91 & 4,68 & 1,17 \\ \mathrm{CaO} & 1,93 & 2,35 & 1,44 & 2,21 & 0,18 & 3,66 & 0,41 & 2,25 & 2,83 & 0,13\end{array}$

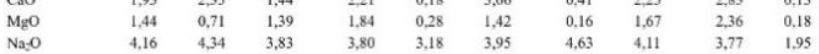

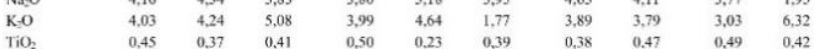
$\begin{array}{lllllllllll}\mathrm{MnO} & 0,45 & 0,37 & 0,41 & 0,50 & 0,23 & 0,39 & 0,38 & 0.47 & 0,49 & 0,42 \\ \mathrm{MnO} & 0,12 & 0,12 & 0,07 & 0,05 & 0,02 & 0,08 & 0,01 & 0,09 & 0,10 & 0,01 \\ & 0,13 & 0,13 & 0,41 & 0,12 & 0,02 & 0,10 & 0,11 & 0,4 & 0,12 & 0,03\end{array}$ $\begin{array}{lllllllllll}\mathrm{M}, \mathrm{O}_{5} & 0,13 & 0,13 & 0,11 & 0,12 & 0,02 & 0,10 & 0,11 & 0,11 & 0,12 & 0,03 \\ \mathrm{SrO} & 0,04 & 0,03 & 0,03 & 0,03 & 0,01 & 0,05 & 0,02 & 0,03 & 0,03 & 0,01\end{array}$

$\begin{array}{lllllllllll}\mathrm{S} S \mathrm{O} & 0,04 & 0,03 & 0,03 & 0,03 & 0,01 & 0,05 & 0,02 & 0,03 & 0,03 & 0,01 \\ \mathrm{BaO} & 0,10 & 0,11 & 0,11 & 0,09 & 0,1 & 0,09 & 0,22 & 0,11 & 0,08 & 0,12\end{array}$

\begin{tabular}{lrrrrrrrrrr} 
LOI & 2,76 & 2,25 & 1,87 & 2,59 & 2,29 & 4,71 & 1,46 & 3,21 & 3,48 & 2,18 \\
Total & 100,6 & 100 & 100,1 & 101 & 99,67 & 100,5 & 99,71 & 99,04 & 96,1 & 101 \\
\hline
\end{tabular}

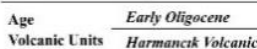

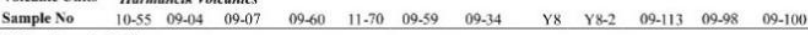
Major elements (verts)

$\begin{array}{lllllllllllll}\mathrm{SiO}_{2} & 46,8 & 46,9 & 49,1 & 48,8 & 47,5 & 48,7 & 50,1 & 49,5 & 51,2 & 49,5 & 50,2 & 50\end{array}$

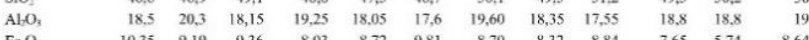

$\begin{array}{lllllllllllll}\mathrm{Fe}_{2} \mathrm{O}_{3} & 10,35 & 9,19 & 9,36 & 8,03 & 8,72 & 9,81 & 8,70 & 8,32 & 8,84 & 7,65 & 5,74 & 8,64 \\ \mathrm{C} e \mathrm{O} & 7.92 & 736 & 7.46 & 7,25 & 7,14 & 7.81 & 7.81 & 6,61 & 7,22 & 4,21 & 7,08 & 6.15\end{array}$

$\begin{array}{lrrrrrrrrrrrr}\mathrm{CaO} & 7,92 & 7,36 & 7,46 & 7,25 & 7,14 & 7,81 & 7,81 & 6,61 & 7,22 & 4,21 & 7,08 & 6,15 \\ \mathrm{MgO} & 3,81 & 4,31 & 5,49 & 4,17 & 4,2 & 4,74 & 2,94 & 4,01 & 4,01 & 4,96 & 3,2 & 3,11\end{array}$

$\begin{array}{lllllllllllll}\mathrm{MgO} & 3,81 & 4,31 & 5,49 & 4,17 & 4,2 & 4,74 & 2,94 & 4,01 & 4,01 & 4,96 & 3,2 & 3,11 \\ \mathrm{NaO}-\mathrm{O} & 3,53 & 3,22 & 3,93 & 5,02 & 4,38 & 3,16 & 4,60 & 4,72 & 3,92 & 4,09 & 4,92 & 3,5\end{array}$

$\begin{array}{lrrrrrrrrrrrr}\text { K-O } & 2,67 & 1,9 & 1,34 & 1,76 & 1,69 & 2,11 & 1,67 & 1,81 & 3,09 & 2,78 & 1,69 & 3,9 \\ \text { TiO. } & 1,06 & 1,02 & 0,95 & 0,85 & 0,81 & 1,0 & 0,92 & 0,83 & 0,87 & 0,94 & 0,87 & 0,84\end{array}$

$\begin{array}{lllllllllllll}\mathrm{TiO}_{2} & 1,06 & 1,02 & 0,95 & 0,85 & 0,81 & 1,0 & 0,92 & 0,83 & 0,87 & 0,94 & 0,87 & 0,84 \\ \mathrm{MnO} & 0,22 & 0,2 & 0,20 & 0,20 & 0,16 & 0,14 & 0,23 & 0,16 & 0,12 & 0,14 & 0,18 & 0,18\end{array}$

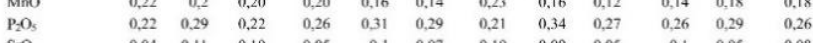

$\begin{array}{rrrrrrrrrrrrr}\mathrm{SrO} & 0,04 & 0,11 & 0,10 & 0,05 & 0,1 & 0,07 & 0,10 & 0,09 & 0,05 & 0,1 & 0,05 & 0,08 \\ \mathrm{BaO} & 0,12 & 0,23 & 0,12 & 0,04 & 0,08 & 0,05 & 0,16 & 0,08 & 0,04 & 0,2 & 0,08 & 0,08 \\ \mathrm{H} & 4,74 & 3,86 & 3,97 & 4,23 & 4,6 & 4,19 & 3,62 & 4,3 & 2,92 & 4,39 & 4,13 & 3,19\end{array}$

\begin{tabular}{lrrrrrrrrrrrr} 
LOI & 4,74 & 3,86 & 3,97 & 4,23 & 4,6 & 4,19 & 3,62 & 4,3 & 2,92 & 4,39 & 4,13 & 3,19 \\
Total & 99,98 & 98,76 & 100,4 & 99,91 & 97,7 & 99,6 & 100,66 & 99,1 & 100,1 & 98 & 97,23 & 98,9 \\
\hline Ale & & 5 & & & &
\end{tabular}

Age Earb Oligocene

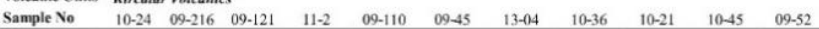
Major elements (wot\%)

$\begin{array}{lllllrrrrrrr}\mathrm{NiO}_{2} & 46,8 & 46,9 & 49,1 & 48,8 & 47,5 & 48,7 & 50,1 & 49,5 & 51,2 & 49,5 & 50,2 \\ \mathrm{Al}_{2} \mathrm{O}_{3} & 18,5 & 20,3 & 18,15 & 19,25 & 18,05 & 17,6 & 19,60 & 18,35 & 17,55 & 18,8 & 18,8\end{array}$

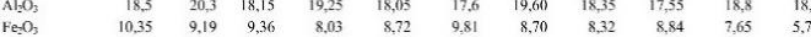

\begin{tabular}{llllllllllll}
$\mathrm{CaO}$ & 7,92 & 7,36 & 7,46 & 7,25 & 7,14 & 7,81 & 7,81 & 6,61 & 7,22 & 4,21 & 7,08 \\
\hline & 3,31 & 4,31 & 5,49 & 4,17 & 4,2 & 4,74 & 2,94 & 4,01 & 4,01 & 4.96 & 3,2
\end{tabular}

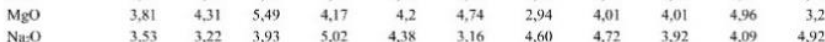

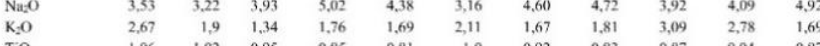

$\begin{array}{lrrrrrrrrrrr}\mathrm{TiO}_{2} & 1,06 & 1,02 & 0,95 & 0,85 & 0,81 & 1,0 & 0,92 & 0,83 & 0,87 & 0,94 & 0,87 \\ \mathrm{MnO} & 0.22 & 0.2 & 0,20 & 0.20 & 0,16 & 0.14 & 0,23 & 0.16 & 0,12 & 0.14 & 0,18\end{array}$

$\begin{array}{llrlllllllll}\mathrm{MnO} & 0.22 & 0,2 & 0,20 & 0,20 & 0,16 & 0.14 & 0,23 & 0,16 & 0,12 & 0.14 & 0,18 \\ \mathrm{PO}_{5} & 0,22 & 0,29 & 0,22 & 0.26 & 0,31 & 0,29 & 0.21 & 0,34 & 0,27 & 0,26 & 0,29\end{array}$

$\begin{array}{lrlllrrrrrrr}\text { Sro } & 0.04 & 0.11 & 0.10 & 0,05 & 0,1 & 0,07 & 0,10 & 0,09 & 0,05 & 0,1 & 0,05 \\ \text { BaO } & 0,12 & 0,23 & 0,12 & 0,04 & 0,08 & 0,05 & 0,16 & 0,08 & 0,04 & 0,2 & 0,08\end{array}$

\begin{tabular}{lrrrrrrrrrrr} 
LOI & 4,74 & 3,86 & 3,97 & 4,23 & 4,6 & 4,19 & 3,62 & 4,3 & 2,92 & 4,39 & 4,13 \\
Total & 99,98 & 98,76 & 100,4 & 99,91 & 97,7 & 99,6 & 100,66 & 99,1 & 100,1 & 98 & 97,23 \\
\hline
\end{tabular}

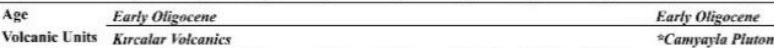

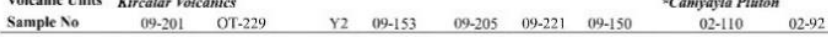

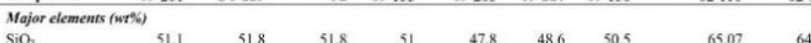

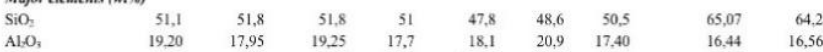

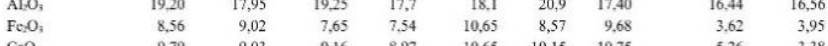

$\begin{array}{lrlrrrrrrr}\mathrm{CaO} & 9,79 & 9,03 & 9,16 & 8,97 & 10,65 & 10,15 & 10,75 & 3,62 & 3,36 \\ \mathrm{MeO} & 3,92 & 4,24 & 2,91 & 3,06 & 5,75 & 3,14 & 6,24 & 1,27 & 1,36\end{array}$

$\begin{array}{lrrrrrrrrr}\mathrm{MgO} & 3,92 & 4,24 & 2,91 & 3,06 & 3,75 & 3,14 & 6,24 & 1,27 & 1,43 \\ \mathrm{Na}-\mathrm{O} & 3,13 & 3,45 & 3,38 & 2,92 & 2,45 & 3,3 & 2,47 & 5,78 & 3,69 \\ \mathrm{~K}=\mathrm{O} & 0,77 & 0,99 & 1,54 & 1,5 & 0,98 & 0,79 & 0,43 & 4,54 & 4,97\end{array}$

$\begin{array}{llllllllll}\mathrm{K}-\mathrm{O} & 0,77 & 0,89 & 1,54 & 1,5 & 0,98 & 0,79 & 0,43 & 4,54 & 4,07 \\ \mathrm{TiO}_{2} & 0,99 & 0,82 & 0,75 & 0,87 & 0,81 & 0,85 & 0,76 & 0,45 & 0,52\end{array}$

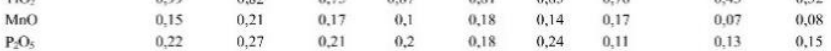

$\begin{array}{llllllll}\mathrm{P}_{2} \mathrm{O}_{5} & 0,22 & 0,27 & 0,21 & 0.2 & 0.18 & 0.24 & 0,11 \\ \mathrm{SrO} & 0,07 & 0,09 & 0,08 & 0,07 & 0,08 & 0,08 & 0,07\end{array}$

$\begin{array}{rrrrrrrr}\mathrm{BaO} & 0,07 & 0,09 & 0,08 & 0,07 & 0,08 & 0,08 & 0,07 \\ \mathrm{~L} & 0,04 & 0,05 & 0,05 & 0,04 & 0,04 & 0,04 & 0,03 \\ \mathrm{~T} & 1,69 & 1,47 & 1,9 & 4,04 & 1,6 & 1,56 & 1,9\end{array}$

$\begin{array}{rrrrrrr}1,69 & 1,47 & 1,9 & 4,04 & 1,6 & 1,56 & 1,9 \\ \text { Total } \quad 99,6 & 99,25 & 98,85 & 98,04 & 99,28 & 98,37 & 100\end{array}$

* The samples numbers and analysis values of Camyayla pluton were obtained from Söylemezoğlu (2009). 
alkaline Upper Miocene Taştepe basalts in the Biga Peninsula (Figure 19a). In addition, considering the comparison of the Eocene volcanic rocks in the study area with the Eocene volcanics developed after collision in the Biga Peninsula and Armutlu Peninsula similar to this region, Eocene volcanism in the Biga Peninsula and vicinity reached the surface with a wide range of varying compositions from basalt to dacite (Figure 19b). The volcanic products in the study area include the most extreme members in this Eocene volcanism series in Western Anatolia.

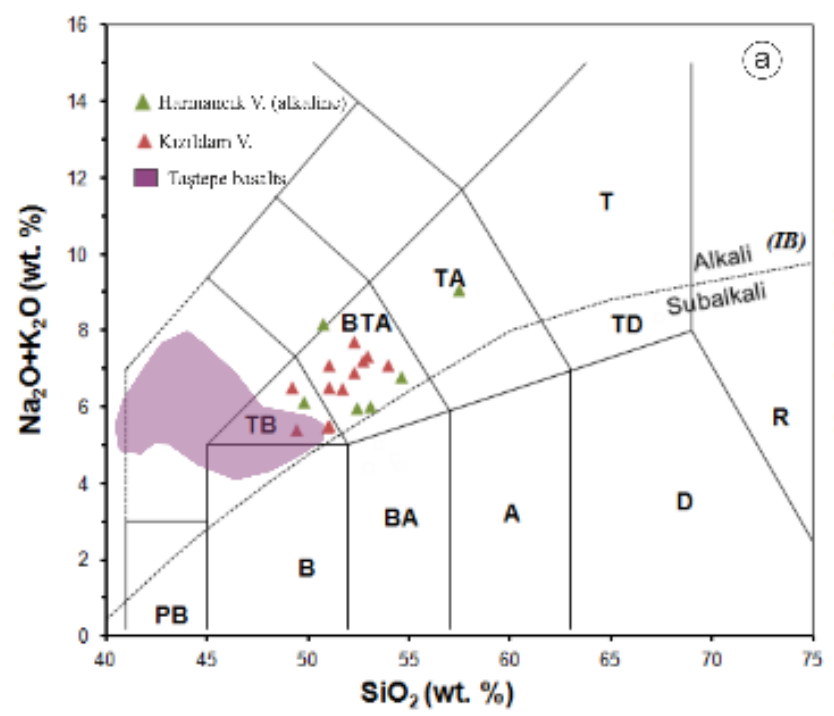

In addition, the changes in character of geochemical features over time are given in Figure 20 in order to clearly see the relationship between Eocene-Oligocene volcanism in the Biga Peninsula and Eocene volcanism in Western Anatolia. Post-collisional mafic volcanism in Western Anatolia changed its character between approximately 38-37 Ma and continued to spread in the Biga Peninsula. Presumably this process reflects the result of tectono-magmatic evolution that took place during that time period. The Eocene volcanism of the Biga Peninsula was active at approximately $37 \mathrm{Ma}$, following plutonism in the same period.

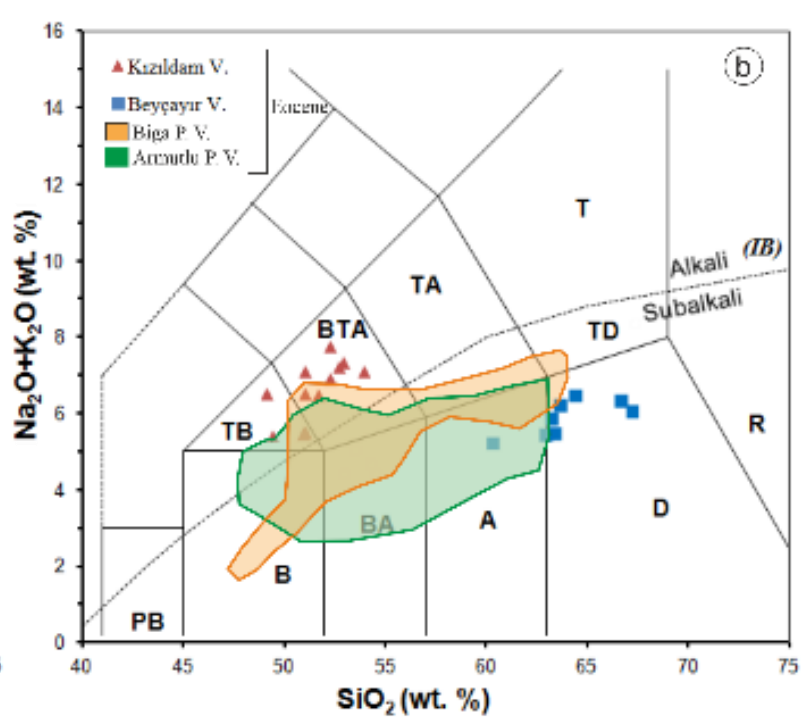

Figure 19. (a) Comparison of Eocene-Oligocene alkaline lavas in the study area with Upper Miocene alkaline lavas in Biga Peninsula and Western Anatolia (For spatial data of Taştepe basalt; Ercan et al., 1995; Aldanmaz et al., 2000; Altunkaynak and Genç, 2008), (b) Comparison of Eocene volcanics in the study area with samples in Western Anatolia. (For spatial data of Biga Peninsula volcanics; Ercan et al., 1995; Altunkaynak and Genç, 2008; Armutlu Peninsula volcanics: Gülmez et al., 2012; Altunkaynak and Dilek 2013).

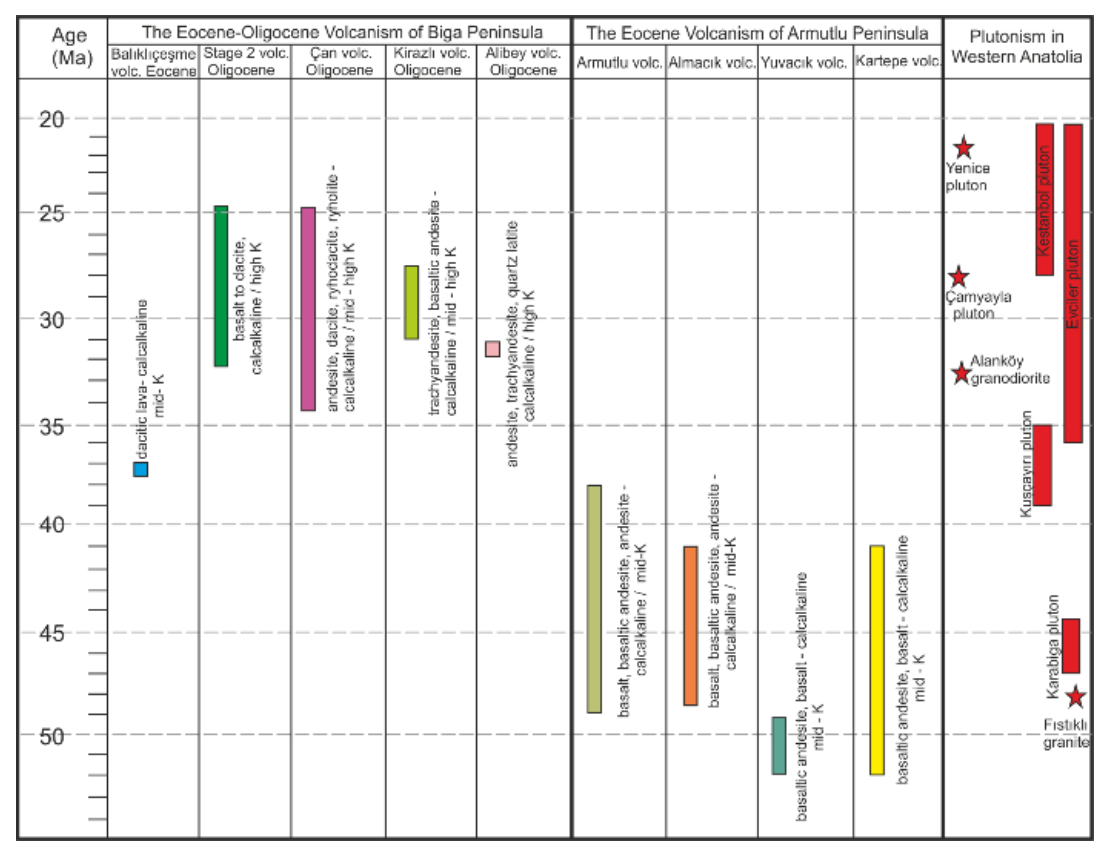

Figure 20. The relationship of Eocene-Oligocene volcanism in Biga Peninsula with Eocene volcanisms in Western Anatolia. (For age and geochemical data; Ercan et al., 1985, 1995; Gülmez et al., 2012; Kürkçüoğlu et al., 2008; Altunkaynak and Dilek, 2013; Delaloye and Bingöl, 2000). 
The most important point to be considered is that the volcanism that started in the Middle Eocene in Western Anatolia has mostly basic, medium-K and calc-alkaline character. In the Biga Peninsula, in previous studies (Ercan et al., 1995; Dönmez et al., 2005) volcanism was characterized as medium-high K. However, the Eocene volcanism and the Eocene-Oligocene transition in volcanism detailed in this study show the existence of alkaline volcanism with basic character in the Eocene period and volcanic products that could be a continuation of them in the ongoing process, rather than what was mentioned so far about the evolution of magmatism.

\section{Acknowledgements}

This study is a part of the Ph.D. studies of the first author. The study was funded by the Çanakkale Onsekiz Mart University, Scientific Research Projects (BAPProject no: 2012/012). The authors would like to express thank to the reviewers for their constructive comments and suggestions on the paper.

\section{References}

Aldanmaz, E., Pearce, J.A., Thirlwall, M.F., Mitchell, J.G. (2000). Petrogenetic evolution of late cenozoic, post collision volcanism in western Anatolia, Turkey. Journal of Volcanology and Geothermal Research, 102, 67-95.

Altunkaynak, Ş., Dilek, Y. (2013). Eocene mafic volcanism in Northern Anatolia: its causes and mantle sources in the absence of active subduction. International Geology Review, 13(55), 1641-1659.

Altunkaynak, Ş., Genç, Ş.C. (2008). Petrogenesis and time-progressive evolution of the cenozoic continental volcanism in the Biga Peninsula, NW Anatolia. Lithos, 102(1), 316-340.

Aslan Z., Erdem, D., Temizel, İ., Arslan, M. (2017). SHRIMP U-Pb zircon ages and whole-rock geochemistry for the Şapçı volcanic rocks, Biga Peninsula, Northwest Turkey: implications for preeruption crystallization conditions and source characteristics. International Geology Review 59 (14), 1764-1785.

Aydın, Ü., Şen, P., Özmen, Ö., Şen, E. (2019). Petrological and geochemical features of Biga Peninsula granitoids, NW Anatolia, Turkey. Bulletin of the Mineral Research and Exploration, 160, 81115.

Aysal N., Öngen S., Keskin M. (2011). Cenozoic Volcano-Stratigraphy and Petrological Evolution of Post-Collisional Volcanic Rocks in Eastern Biga Peninsula, NW, Anatolia, Turkey. International Multidisciplinary Scientific GeoConference SGEM 2011, Bulgaristan, pp. 19-26.

Aysal, N. (2015). Mineral chemistry, crystallization conditions and geodynamic implications of the Oligo-Miocene granitoids in the Biga Peninsula, Northwest Turkey. Journal of Asian Earth Science 105, 68-84.

Bingöl E., Akyürek B., Korkmazer B. (1975). Biga Yarımadasının Jeolojisi ve Karakaya Formasyonunun
Bazı Özellikleri. Cumhuriyetin 50. Y1lı Yerbilimleri Kongresi Tebliğleri, pp. 70-77.

Bingöl, E., Delaloye, M., Ataman, G. (1982). Granitic intrusion in Western Anatolia: a contribution to the geodynamic study of this area. Eclogae Geologicae Helvetiae, 75(2), 437-446.

Birkle, P., Satır, M. (1995). Dating, geochemistry and geodynamic significance of the tertiary magmatism of the Biga Peninsula, NW-Turkey. Geology of the Black Sea Region. In: Erler, A., Ercan, T., Bingöl, E., Örçen, S. (Eds.) Geology of the Black Sea Region (pp. 171-180), MTA, Ankara.

Borsi, S., Ferrar, C., Innocenti, F., Mazzudi, R. (1972). Geochronology and petrology of recent volcanics of eastern Aegean Sea. Bulletin of Volcanology, 36, 473-496.

Bozkaya, G., Gökçe, A. (2009). Lead and sulfur isotope studies of the Koru (Çanakkale, Turkey) lead-zinc deposits. Turkish Journal of Earth Sciences, 18, $127-$ 137.

Cas, R.A.F., Wright J.V. (1987). Volcanic Successions. Modern and Ancient, London, Boston, Sydney, Wellington: Allen \& Unwin. 528 p.

Dayal, A. (1984). Yenice (Çanakkale) granitinin petrografisi ve buna bağll cevherleşmeler (Doktora tezi). Dokuz Eylül Üniversitesi, İzmir, Türkiye.

Dayal, A., Özgenç, İ. (2000). Yenice yöresinde skarn oluşturan plutonik ve volkanik kayaçlarin radyometrik yaşı (Çanakkale - Biga Yarımadası). 53. Türkiye Jeoloji Kurultayl, Bildiri Özleri Kitabı (pp. 296-297), Ankara, Türkiye.

Delaloye, M., Bingöl, E. (2000). Granitoids from Western and Nortwestern Anatolia: geochemistry and modeling of geodynamic evolution. International Geology Review, 42, 241-268.

Dönmez, M., Akçay, A.E., Genç, Ş.C., Acar, Ş., (2005). Biga Yarımadasında orta-üst eosen volkanizmasi ve denizel ignimbiritler. MTA Dergisi, 131, 49-61.

Ercan, T., Satır, M., Steinitz, G., Dora, A., Sarıfakıoğlu, E., Adis, C., Walter, H.J., Yıldırım, T. (1995). Biga Yarımadası ile Gökçeada, Bozcaada ve Tavşan Adalarındaki KB Anadolu tersiyer volkanizmasinin özellikleri. MTA Dergisi, 117, 55-86.

Erdem, D., Aslan, Z. (2015). Kalk-alkalen Şapçı (Balıkesir) Volkanitlerin Petrografisi ve Petrolojisi: Biga Yarımadası'nda (Kuzeybatı Türkiye) Çarpışma ile İlişkili Volkanizma. Türkiye Jeoloji Bülteni 58, 122.

Genç, S.C. (1998). Evolution of the Bayramiç magmatic complex, Northwestern Anatolia. Journal of Volcanology and Geothermal Research, 85, 233249.

Gülmez, F., Genç, S.C., Keskin, M., Tüysüz, O. (2012). A post-collision slab-breakoff model for the orgin of the middle Eocene magmatic rocks of the Armutlu Almacık Belt, NW Turkey and its regional implications. In: Robertson, A.H.F., Parlak, O., Ünlügenç U.C. (Eds.), Geological Development of Anatolia and the Easternmost Mediterranean Region. Geological Society of London, Special Publications. $372 \mathrm{p}$. 
İncekara, A., Şeker, D., Tezcan, C., Bozkurtoglu, E., Gazioğlu, C. (2017). Interpreting Temperature Based Discontinuity and Roughness of Rock Surfaces by Using Photogrammetric Technique. International Journal of Environment and Geoinformatics, 4(3), 206-213.doi.10.30897/ijegeo.348806.

Irvine, T.N., Baragar, W.A.R. (1971). Aguide to chemical classification of common volcanic rocks. Canadian Journal of Earth Sciences, 8, 523-547.

Kamakçı, N., Aldanmaz, E., Langereis, C.G., Spell, T.L., Gürer, Ö.F., Zanetti, K.A. (2007). Late Miocene transcurrent tectonics in NW Turkey: Evidence from paleomagnetism and 40Ar/39Ar dating of the alkaline rocks. Geological Magazine, 144(2), 379392.

Karacık, Z. (1995). Ezine-Ayvacık (Çanakkale) dolayında genç volkanizma plutonizma ilişkileri (Doktora tezi). İstanbul Teknik Üniversitesi, İstanbul, Türkiye.

Karacık, Z., Yılmaz, Y., Pearce, J.A., Ece, Ö.I. (2008). Petrochemistry of the South Marmara granitoids, Northwest Anatolia, Turkey. International Journal of Earth Sciences (Geologische Rundschau), 97, 11811200.

Krushensky, R.D. (1976). Neogene calc-alkaline extrusive and intrusive rocks of the Karalar-Yeşiller area, Northwest Anatolia, Turkey. Bulletin of Volcanology, 40, 336-360.

Kürkçüoğlu, B., Furman, T., Hanan, B. (2008). Geochemistry of post-collisional mafic lavas from the North Anatolian Fault Zone, Northwestern Turkey. Lithos, 101, 416-434.

Le Bas, M.J., Le Maitre, R.W., Streckeisen, A., Zanettin, B. (1986). A chemical classification of volcanic rocks based on the total alkali-silica diagram. Journal of Petrology, 27, 745-750.

Okay, A.I., Satır M. (2000). Coeval plutonism and metamorphism in a latest Oligocene metamorphic core complex in Northwest Turkey. Geological Magazine, 137, 495-516.

Peccerillo, A., Taylor, S.R. (1976). Geochemistry of Eocene calcalkaline volcanic rocks from the Kastamonu Area, Northern Turkey. Contributions to Mineralogy and Petrology, 58, 63-81.

Rollinson, H. (1993). Using Geochemical Data: Evaluation, Presentation, Interpretation. Newyork: Longman Scientific \& Technical. 352 p.

Saatçi E.S., Aslan Z. (2018). Petrography and petrology of The Yürekli (Balıkesir) volcanics: an example of post-collisional felsic volcanism in the Biga peninsula (NW Turkey). Turkey. Bulletin of the Mineral Research and Exploration. 157, 103-120.

Shaheen Zafar, F., Ayub, Z., Karim, A., Zahid, M., Bat, L. (2018). Seasonal variations in physico-chemical parameters of Buleji and Paradise Point rocky shores at Karachi coast, International Journal of Environment and Geoinformatics, 5(2), 154168.doi.10.30897/ijegeo.418709.

Siyako, M., Burkan, K.A., Okay, A.I. (1989). Biga ve Gelibolu Yarımadaları tersiyer jeolojisi ve hidrokarbon olanaklari. Turkish Association of Petroleum Geologist Bulletin, 1, 183-199.

Söylemezoğlu S., (2009). Kuzey Batı Anadolu'da Çanakkale-Çan yöresi volkanik kayaçlarının jeolojik ve petrolojik özellikleri ve evriminin araştırılması. (Doktora tezi), İstanbul Teknik Üniversitesi, İstanbul, Türkiye.

Yılmaz, M. (2004). Kirazlı (Çanakkale) bölgesinin volkanik kayalarının petrografik-petrolojik incelemesi ve çıkış merkezleri ile yapısal unsurların araştırılması. (Yüksek lisans tezi), İstanbul Teknik Üniversitesi, İstanbul, Türkiye.

Yilmaz, Y. (1989). An approach to the origin of young volcanic rocks of western Turkey. In: Şengör, A.M.C. (Ed.) Tectonic Evolution of the Tethyan Region (pp. 159-189), Kliwer, The Hague.

Yılmaz, Y. Genç, Ş.C., Karacık, Z., Altunkaynak, Ş., (2001). Two contrasting magmatic associations of NW Anatolia and their tectonic significance. Journal of Geodynamics, 31, 243-271. 